\title{
Demographic variability and scales of agreement and disagreement over resource management restrictions
}

\author{
Tim R. Mc Clanahan $^{1}$ and $\underline{\text { Caroline A. Abunge }}^{1}$
}

\begin{abstract}
Conflicts over the imposition of restrictions in common-pool resources management institutions are expected to arise from variations in human values, perceptions of justice, and the disparate demographic scales of benefits and costs. We hypothesized and tested a series of propositions about how the demographic scale and context of common restrictions would influence coral reef fisheries of 4 African countries. We surveyed the preferences and perceived benefits of 1849 people in 89 fish landing sites for 6 common restrictions of increasing severity. Variability in perceived benefits within and between neighboring communities was evaluated to determine how perceptions changed with the severity of the proposed benefit/cost restriction scale, perceived benefits, disparities between beneficiaries, and national context. Within-community variability declined strongly $\left(r^{2}>0.90\right)$ as perceived benefit increased but was either weak or not significantly associated with the neighbor-community's variation. Within-community variation was less than between-community variation and differed by nation. There was generally broader scale agreement on the benefits of weaker restrictions of minimum sizes of fish and allowable fishing gear and more disagreement on stronger restrictions on species, time, and space use. Reduced variability was strongly associated with less perceived disparity in the benefits received by local versus government beneficiaries. These findings indicate potential conflicts between neighboring communities for most, but particularly the strongest, restrictions. Consequently, the broadscale management benefits of strong restrictions will need to address between-community compliance and justice procedures. Demographic variability requires coordinating governance and management to account for restriction-specific variability in the perceptions of management benefits.
\end{abstract}

Key Words: comanagement; equity; fisheries policies; homophily; social dilemmas; social-ecological trade-offs; western Indian Ocean

\section{INTRODUCTION}

Human values, subsequent preferences, cost/benefit consideration, and associated trade-offs will influence management choices (Klöckner 2013, Daw et al. 2015, Hicks et al. 2015). When values and costs and benefits do not match the expectations of all stakeholders, resultant actions can be seen as unfair or illegitimate and result in dysfunctional natural resource management (Cumming et al. 2006, Sundström 2015, Bennett 2016). Consequently, evaluating stakeholder preferences, perceptions of net benefits, and effectiveness should help to identify potential sources of conflicts (Daw et al. 2011, McClanahan and Abunge 2016). However, values, trade-offs, cooperation, and compliance vary for different stakeholder professions, such as users, traders, and managers, and demographic scales, such as individual, family, community, and local to global governments (Daw et al. 2016). Therefore, coordination and leadership within and above the community level should be critical for successful common-pool resources management (CPRM; Gutiérrez et al. 2011, Giakoumi et al. 2018).

The between-community aspects of CPRM have been evaluated less frequently, possibly being more challenging to assess and therefore a marginalized area of CPRM research (Cox et al. 2010, Ostrom 2010, Koontz et al. 2015). Therefore, cultural and governance system differences that range from the individual to state are less considered, researched, and critically evaluated (Saunders 2014). Further, managing common-pool resources is difficult when resources are used by either many or sparsely distributed users in areas with unclear boundaries, where rule breakers are difficult to detect and sanction and between-group forums do not exist (Agrawal 2003, Cudney-Bueno and Basurto 2009). Further, the scarcity of resources will influence the emergence and need for conflict resolution as well as the feasibility of the implementing options (Hardin 1968, Odum 1982).
Countries with a strong rule of law having legislation, taxation, enforcement, and government penetration should ensure that rules are agreed on, shared, and enforced by stakeholders (Fukuyama 2011). These conditions are more likely where the values, wealth, and costs/benefits promote compliance and governance effectiveness (Inglehart and Welzel 2005, Hofstede et al. 2010, McClanahan and Rankin 2016). Therefore, social actors, contexts, and coordination from the individual to higher demographic and governance scales are expected to be critical to CPRM success. Critical reviews of CPRM conclude that investigators have not fully considered the influences of demographic heterogeneity, market penetration, economic development, and state policies (Agrawal 2003, Araral 2014). Conflicts and failures in CPRM can include a number of factors but are expected when individuals, communities, and their neighbors lack shared perceptions, forums, leaders, and agreements on restrictions and enforcement (Agrawal et al. 2013, Koontz et al. 2015). When neighbors do not share values, perceptions, and costs/benefits, they can fail to restrict some resource extraction behaviors, which can lead to matching only the most common and minimal restrictions (Agrawal et al. 2013).

Management restrictions differ in their costs and benefits and differentially accrue to professions based on the economic scales of the profession's dependency (Table 1). Resource managers, for example, are likely to see benefits across many economic sectors, i.e., fishing and tourism, and over longer periods of time than resource users, i.e., species preservation and spillover of fish from fisheries closures. Poor recognition of economic development and these differential scales of dependency can therefore lead to cost/ benefit context-policy mismatches and CPRM failures (Araral 2014, Daw et al. 2016, McClanahan and Abunge 2017). For example, because fishing impacts on vagile species are difficult to assess and more likely to negatively accrue beyond the local fishing 
Table 1. Hypotheses of the scale of costs and benefits of six different fisheries management restrictions. Hypothesized gradient of perceived reduction in access to individual resource users for common fisheries management options. Organized along the hypothesized least to most restrictive to the individual, i.e., high to low cost/benefit, from left to right while acknowledging cost/benefit overlaps.

\begin{tabular}{|c|c|c|c|c|c|c|}
\hline Costs and benefits & $\begin{array}{l}\text { Minimum size } \\
\text { of fish }\end{array}$ & $\begin{array}{l}\text { Gear use } \\
\text { restriction }\end{array}$ & Temporal closures & $\begin{array}{l}\text { Full restrictions on } \\
\text { the species }\end{array}$ & $\begin{array}{l}\text { Area-based } \\
\text { management with or } \\
\text { without core closures }\end{array}$ & Permanent closures \\
\hline $\begin{array}{l}\text { User access to } \\
\text { resource implication }\end{array}$ & $\begin{array}{l}\text { Reduced for } \\
\text { period of early } \\
\text { growth }\end{array}$ & $\begin{array}{l}\text { Initial higher } \\
\text { capital entry costs }\end{array}$ & $\begin{array}{l}\text { Reduced for } \\
\text { periods of time }\end{array}$ & $\begin{array}{l}\text { Reduced catch } \\
\text { options }\end{array}$ & $\begin{array}{l}\text { Various spatial access } \\
\text { restrictions }\end{array}$ & $\begin{array}{l}\text { Loss of fishing area and } \\
\text { resources }\end{array}$ \\
\hline Temporal costs & $\begin{array}{l}\text { Lost access } \\
\text { during early } \\
\text { period of } \\
\text { growth }\end{array}$ & $\begin{array}{l}\text { Gear selection } \\
\text { decisions }\end{array}$ & $\begin{array}{l}\text { Proportional to } \\
\text { closure period } \\
\text { from months to } \\
\text { years }\end{array}$ & $\begin{array}{l}\text { Permanent losses } \\
\text { over time }\end{array}$ & $\begin{array}{l}\text { Temporary losses of } \\
\text { access to resources }\end{array}$ & Permanent displacement \\
\hline Temporal benefits & $\begin{array}{l}\text { Recovery of } \\
\text { larger fish }\end{array}$ & $\begin{array}{l}\text { Recovery of } \\
\text { larger fish }\end{array}$ & $\begin{array}{l}\text { Periods of high } \\
\text { harvests }\end{array}$ & $\begin{array}{l}\text { Recovery of } \\
\text { protected species }\end{array}$ & $\begin{array}{l}\text { Recovery of } \\
\text { protected species }\end{array}$ & $\begin{array}{l}\text { Recovery of resource } \\
\text { leading to spillover }\end{array}$ \\
\hline Spatial costs & None & Transport of gear & $\begin{array}{l}\text { Periodic spatial } \\
\text { enforcement }\end{array}$ & $\begin{array}{l}\text { Identification and } \\
\text { enforcement of } \\
\text { species }\end{array}$ & $\begin{array}{l}\text { Complex and } \\
\text { nuanced spatial } \\
\text { enforcement }\end{array}$ & $\begin{array}{l}\text { Full-time protection of } \\
\text { closure areas }\end{array}$ \\
\hline Spatial benefits & $\begin{array}{l}\text { Increased } \\
\text { broadscale } \\
\text { catch }\end{array}$ & $\begin{array}{l}\text { Increased } \\
\text { broadscale catch }\end{array}$ & $\begin{array}{l}\text { Temporary } \\
\text { increases in } \\
\text { biomass and } \\
\text { spillover of high } \\
\text { catches }\end{array}$ & $\begin{array}{l}\text { Recovery of } \\
\text { protected species } \\
\text { over large areas }\end{array}$ & $\begin{array}{l}\text { Increases in biomass, } \\
\text { species, and } \\
\text { ecosystem services } \\
\text { over large areas }\end{array}$ & $\begin{array}{l}\text { Recovery of stocks and } \\
\text { species and potential } \\
\text { long-term spillover } \\
\text { effects }\end{array}$ \\
\hline Social disparity & $\begin{array}{l}\text { Low but can } \\
\text { exclude } \\
\text { youngest, } \\
\text { female, and } \\
\text { poorest fishers } \\
\text { and dealers }\end{array}$ & $\begin{array}{l}\text { Low but can } \\
\text { exclude poorest } \\
\text { fishers and } \\
\text { dealers lacking } \\
\text { capital for } \\
\text { preferred gear }\end{array}$ & $\begin{array}{l}\text { Moderate, } \\
\text { temporarily } \\
\text { excludes resource } \\
\text { users without } \\
\text { alternatives }\end{array}$ & $\begin{array}{l}\text { Moderate, excludes } \\
\text { resource users } \\
\text { dependent on the } \\
\text { specific species }\end{array}$ & $\begin{array}{l}\text { Moderate by creating } \\
\text { various gradients of } \\
\text { spatial and temporal } \\
\text { exclusion }\end{array}$ & $\begin{array}{l}\text { Depends on the size of } \\
\text { the area, time required } \\
\text { for recovery, and benefits } \\
\text { to national economy, } \\
\text { elite investors, and } \\
\text { tourism sectors }\end{array}$ \\
\hline
\end{tabular}

grounds, restricting gear is expected to be more preferred than restrictions on the capture of wide-ranging species. Managers, on the other hand, will consider the needs of vagile species on scales larger than local fish landing sites. Previous studies have supported this disparity in scale contention and identified a number of potential areas of management conflicts (McClanahan and Abunge 2016). Successful management needs to negotiate positions that integrate national with within- and between-community preferences. This requires understanding the pervasiveness of preferences and also boundaries of potential conflicts. To assist with this understanding, we evaluated differences in within- and between-community preferences for common-pool fisheries management options in four African nations.

We asked if neighboring communities differ in their preferences and if between-community preferences vary with restrictions and national contexts. The common fisheries restrictions examined were minimum size of fish, allowable gear, species restrictions, temporal closures, area-based management, and permanent closures (Table 1). Our previous study found contextual evidence for perceived disparity in benefits of restrictions based on profession (user vs. manager) and country but failed to examine the intercommunity perceptions (Table 2). Although previous findings supported the restriction-gradient assertion in the more developed countries of Kenya and Tanzania, they also uncovered untheorized variations between communities, professions, and nations (McClanahan and Abunge 2016). Resource managers' responses, for example, generally failed to acknowledge the proposed cost-benefit gradient and scaled most restriction benefits high and social disparity low, with some country-specific deviations (Table 3). Consequently, the differences between managers' and resource users' responses increased across the proposed restriction gradient, with some country-specific variation. We concluded that because managers' economic dependence is on a larger spatial and temporal scale, i.e., regional or national governments, they do not directly experience local costs and believe long-term and large-scale benefits will eventually accrue to local scales. Some of the observed differences between users and managers were hypothesized to result from national contexts of wealth, human development, and the histories of protected areas.

The question we addressed is whether perceptions about restrictions are uniform between neighboring communities when examining restriction-specific differences. In principle, restriction costs and benefits should be similar and appreciated broadly within a profession and nation. Perceptions may, however, be influenced by local contexts of shared experiences, isolation, neighborhood competitions, education, forums, benefit sharing, and specific wealth and governance contexts. Consequently, common socioeconomic factors such as residency, education, communications, wealth, age, and perceptions of fairness and justice are expected to influence these perceptions (Schroeder et al. 2003, Inglehart and Welzel 2005, Starmans et al. 2017). Therefore, a null hypothesis proposes no differences in perceptions of specific restrictions between neighboring communities. However, based on this discussion, we can predict 
Table 2. Summary of reported perceived net benefits of common fisheries restrictions of interviewed managers and resource users in the four studied countries Perceived differences (managers - resource users) between the benefits scaled by managers and resource users. Results are summarized from (McClanahan and Abunge 2016) based on interviews with 2100 stakeholders. + , perceived positive benefits; 0 , perceived neutral benefits; -, perceived negative benefits.

\begin{tabular}{|c|c|c|c|c|c|c|c|c|}
\hline \multirow[b]{2}{*}{ Management options } & \multicolumn{2}{|c|}{ Kenya } & \multicolumn{2}{|c|}{ Tanzania } & \multicolumn{2}{|c|}{ Madagascar } & \multicolumn{2}{|c|}{ Mozambique } \\
\hline & $\begin{array}{c}\text { Resource } \\
\text { users }\end{array}$ & Managers & $\begin{array}{c}\text { Resource } \\
\text { users }\end{array}$ & Managers & $\begin{array}{l}\text { Resource } \\
\text { users }\end{array}$ & Managers & $\begin{array}{c}\text { Resource } \\
\text { users }\end{array}$ & Managers \\
\hline Minimum size of fish & + & + & 0 & + & + & + & + & + \\
\hline Gear use restriction & + & + & + & + & + & + & + & + \\
\hline Temporal closures & 0 & + & - & + & + & + & + & + \\
\hline $\begin{array}{l}\text { Full restriction on the } \\
\text { species }\end{array}$ & 0 & - & - & 0 & - & + & 0 & + \\
\hline $\begin{array}{l}\text { Area-based management } \\
\text { with or without core } \\
\text { closures }\end{array}$ & 0 & + & 0 & + & + & + & + & + \\
\hline Permanent closures & 0 & + & 0 & + & + & + & 0 & + \\
\hline
\end{tabular}

that differences between perceptions of restrictions of the neighboring community will (1) be higher than within-community variation; (2) increase with the spatial and temporal scale of the specific restriction severity and potential net benefits; (3) decline with perceptions of fairness, wealth, education, and residence time; and (4) vary by the interrelated factors of human population density, strength of the national economies, communication, governance strength, histories of protective management, and equity. These hypotheses guided our evaluation of variability within and between 89 reef-fishing communities in the countries of Kenya, Tanzania, Madagascar, and Mozambique. This information was then used to evaluate the spatial distribution of this variability and potential areas for conflict and cooperation over specific restrictions.

\section{STUDY REGION, DESIGN, AND SITES}

\section{Regional overview}

These nations are heavily reliant on natural resources and differ in their experiences with conservation and fisheries management (Hicks 2011). Eastern and southern African countries have variable economies but are generally poor and highly reliant on natural resources (Levin et al. 2018; Table 4, Fig. 1). The studied nations have different ethnic, colonial, and postcolonial histories, and their recent international trade and governance affiliations reflect these histories. GDP declines along the Kenya, Tanzania, Madagascar, and Mozambique sequence, as do the taxes spent as percentage of GDP. There was a legal and social movement toward decentralization of governance and resource management in the region that was at different stages of development and donor support and seldom fully implemented when we collected our data (Cinner et al. 2012).

Kenya has followed British-style parliamentary governance with a strong central government. Its economic policy is capitalistic with open and free trade and weak regulations. It is the richest of the four countries and has the highest GINI (a measure of economic inequality) coefficients, access to advanced education, government revenues and spending, and high judicial effectiveness governance indicators, but low political stability and rule of law. Relatively high education and government revenue maintain national engagement and control over resource management that, at times, has conflicted with local community management (McClanahan et al. 1997).

Fig. 1. Map showing the distribution of fishing communities in the four countries. Sites were clustered based on the similarity of their responses to the perceived benefits of management restrictions. The nine clusters were then scaled by their mean scaling of the perceived benefits of the six management restrictions from highest in green to lowest in red.

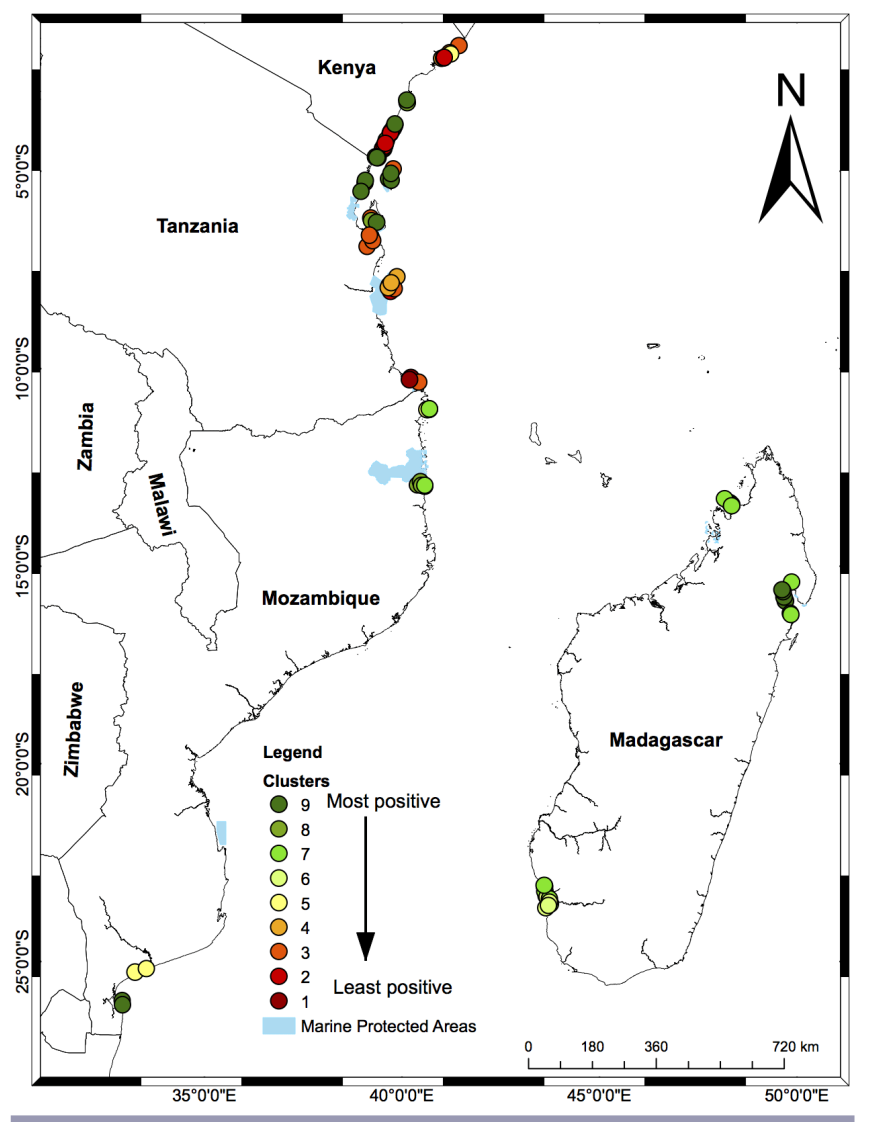


Table 3. Perceived differences (managers - resource users) between the net benefits scaled by managers and resource users. Results are summarized from (McClanahan and Abunge 2016) based on interviews with 2100 stakeholders. ++ , large difference in perceived benefit/disparity; +, small difference in perceived benefit/disparity; 0 , no or negative difference in perceived benefit/disparity.

\begin{tabular}{|c|c|c|c|c|c|c|c|c|}
\hline \multirow[b]{2}{*}{ Management options } & \multicolumn{2}{|c|}{ Kenya } & \multicolumn{2}{|c|}{ Tanzania } & \multicolumn{2}{|c|}{ Madagascar } & \multicolumn{2}{|c|}{ Mozambique } \\
\hline & $\begin{array}{c}\text { Scaled } \\
\text { benefits }\end{array}$ & $\begin{array}{c}\text { Social } \\
\text { disparity }\end{array}$ & $\begin{array}{c}\text { Scaled } \\
\text { benefits }\end{array}$ & $\begin{array}{c}\text { Social } \\
\text { disparity }\end{array}$ & $\begin{array}{c}\text { Scaled } \\
\text { benefits }\end{array}$ & $\begin{array}{c}\text { Social } \\
\text { disparity }\end{array}$ & $\begin{array}{c}\text { Scaled } \\
\text { benefits }\end{array}$ & $\begin{array}{c}\text { Social } \\
\text { disparity }\end{array}$ \\
\hline Minimum size of fish & 0 & + & + & 0 & 0 & 0 & 0 & 0 \\
\hline Gear use restriction & 0 & 0 & + & 0 & 0 & 0 & + & 0 \\
\hline Temporal closures & ++ & + & ++ & + & 0 & 0 & + & 0 \\
\hline $\begin{array}{l}\text { Full restriction on the } \\
\text { species }\end{array}$ & 0 & 0 & ++ & 0 & 0 & 0 & + & 0 \\
\hline $\begin{array}{l}\text { Area-based management } \\
\text { with or without core } \\
\text { closures }\end{array}$ & ++ & ++ & ++ & ++ & 0 & 0 & 0 & 0 \\
\hline Permanent closures & ++ & ++ & ++ & ++ & 0 & 0 & + & 0 \\
\hline
\end{tabular}

Tanzania has had a strong central party with a prosocialist government that historically has controlled the economy and pricing, but these controls have declined over time. Tanzania has the lowest GINI coefficient among the countries, high rule of law, and low judicial effectiveness, and the dominant party and government has had a strong influence and a history of conflicts with coastal communities over resource management (Walley 2004, Benjaminsen and Bryceson 2012, Kamat 2014, Katikiro et al. 2015).

Madagascar has a French-style representative democracy and free-trade economy but has low tax revenue and spending and weak national governance, communications, and judicial penetration and effectiveness. Madagascar is poor and has a low population density, but some coastal regions are highly reliant on fisheries resources. Because national government penetration is low, international donors and trust funds often support a customary management system called dina (Cinner et al. 2009, Carrett 2013).

Mozambique has moved between socialist and more capitalist forms of government and economies with strong regional political divisions. Protracted civil wars since 1990 eventually resulted in a constitution that allowed private property enterprises and decentralization of community resource management. It is among the poorest countries in the world, but with moderate governance indicators for Africa. The coastal population density is low, but the arid conditions and cultural preferences make coastal people dependent on fisheries resources that need to be imported to meet the demand. During the time of this study, there was high political stability, and there were moderately high governance indicators.

The four countries have marine protected areas (MPAs) and closures, but they vary in the protected area, management regulations, and enforcement of fishing restrictions and closures (Wells et al. 2007). Madagascar had the least area in closures, and the few legal ones at the time of this study were not well enforced, but coral reef fish resources were in moderate condition except close to population centers (McClanahan and Jadot 2017). Mozambique and Tanzania had a larger area in closure but considerable variation in management effectiveness (McClanahan et al. 2009b, Gill et al. 2017). The Inhaca MPA, established in 1968, and the large Bazaruto MPA $\left(1430 \mathrm{~km}^{2}\right)$, established in 1986, greatly skew Mozambique's MPA statistics. The other large protected area, the Quirimba Marine National Park, established in 2002, lacked effective closures, and other management systems were weak (Gill et al. 2017, McClanahan and Muthiga 2017). There is a history of conflict in many Tanzanian fisheries and parks as well as low compliance (Horrill et al. 2000). Kenya has the largest percentage of well-protected reefs in closures, but gearrestricted reserves are poorly managed (McClanahan et al. 2005).

\section{Study sites and design}

Fishing villages were visited between 2008 and 2012 with the intention of evaluating their management preferences (McClanahan et al. 2008, 2012, 2014). In most cases, we selected a group of three to five landing sites near or associated with some specific management systems, such as an MPA or a proposed management system. Fishers were often strongly associated with a fishing ground and landing site, but this may largely be because of limited access or affordability of transportation rather than a sense of ownership. Fishers often walk or use bicycles to reach landing sites, and this restricts their movements. Fishers most often used body- and wind-powered boats, and engine-powered boats were uncommon.

Most sampled neighboring villages were close to each other, but some were far enough apart that they would seldom interact. Consequently, we set a maximum distance of $40 \mathrm{~km}$ for evaluating neighboring landing site interactions. Therefore, a total of 89 landing sites were sampled, which resulted in 60 pairwise nearestneighbor comparisons for sites that were $<40 \mathrm{~km}$ apart. The mean linear distance for these 60 comparisons was $8.99 \pm 8.48 \mathrm{~km}( \pm$ standard deviation), which we consider an appropriate scale for potentially interacting at the scale of the fishing grounds. With emerging efforts to promote local control and comanagement, there were increasing numbers of local management groups formed and associations with these groups. Although similar in many ways, they assumed different names in the four western Indian Ocean (WIO) countries of study. For example, in Kenya and Tanzania, the fisher organizations were known as Beach Management Units, and in Mozambique and Madagascar, they were called Conselho Comunitario de Pesca and Village Fisheries 
Table 4. Coastal human population density, GDP income, inequality, and governance indicators in 2011 in the four studied countries. GDP is in U.S. dollars. Governance is a 0 to 100 scale for various metrics. Table organized from most to least wealthy people and governments. GINI index (a measure of economic inequality) and governance indicators data extracted from World Bank and Index of Economic Freedom-The Heritage Foundation. Marine protected information taken from Wells et al. (2007) and Wildlife Conservation Society database; western Indian Ocean closure ages where ages of marine protected areas (MPAs) per country are based on mean (+ standard deviation [SD]) of years of development for various protected and no-take areas in 2010. Fisheries information is from Sea Around Us data of 2010. PPP, purchasing power parity.

\begin{tabular}{|c|c|c|c|c|c|}
\hline Categories & Variables & Kenya & Tanzania & Madagascar & Mozambique \\
\hline Demographics & Coastal population per $\mathrm{km}^{2}$ & 44.1 & 49.1 & 24.2 & 27.1 \\
\hline \multirow[t]{6}{*}{ Income and taxes } & National wealth rank $^{\dagger}$ & $149 / 198$ & $155 / 198$ & $175 / 198$ & $180 / 198$ \\
\hline & Income per capita (PPP), $\$$ & 3208 & 2908 & 1462 & 1186 \\
\hline & Government spending, \$ & 77.9 & 89.5 & 93.2 & 58.2 \\
\hline & Taxes, $\%$ GDP & 30.0 & 30.0 & 20.0 & 35.4 \\
\hline & Expenditure, \% GDP & 28.6 & 18.8 & 15.5 & 35.4 \\
\hline & Corruption control and rank, $\%$ & 25.9 & 44.8 & 56.1 & 52.8 \\
\hline Inequality, 2005 & GINI coefficient, $\%$ & 48.5 & 37.8 & 42.7 & 45.6 \\
\hline \multirow[t]{6}{*}{ Governance indicators } & Political stability & 20.3 & 58.5 & 35.9 & 68.9 \\
\hline & Governance effectiveness & 45.8 & 48.9 & 27.3 & 44.3 \\
\hline & Voice and accountability & 46.3 & 51.4 & 29.0 & 49.1 \\
\hline & Rules of law & 26.6 & 45.8 & 38.8 & 44.9 \\
\hline & Judicial effectiveness & 42.7 & 28.8 & 21.4 & 32.4 \\
\hline & Average governance indicators & 36.3 & 46.7 & 30.5 & 48.0 \\
\hline \multirow{2}{*}{$\begin{array}{l}\text { Access to information and } \\
\text { communication }(\%)^{\ddagger}\end{array}$} & Mobile phone subscription & 80.7 & 75.9 & 44.1 & 74.2 \\
\hline & Internet users & 45.6 & 5.4 & 4.2 & 9.0 \\
\hline \multirow[t]{2}{*}{ Education and knowledge $(\%)^{\dagger}$} & Access to basic knowledge & 79.5 & 68.8 & 74.4 & 68.8 \\
\hline & Access to advanced education & 37.7 & 18.1 & 16.1 & 10.3 \\
\hline \multirow[t]{4}{*}{ Fisheries information $^{\S}$} & Artisanal fishery (t/yr) & 6018 & 95,305 & 64,870 & 51,433 \\
\hline & Subsistence fishery (t/yr) & 2727 & 15,354 & 56,270 & 56,578 \\
\hline & Industrial fishery (t/yr) & 588 & 14,673 & 53,416 & 42,336 \\
\hline & $\begin{array}{l}\text { Dependency on fish for humans } \\
\text { (quartiles categorization) }\end{array}$ & Low & High & Medium & Low \\
\hline \multirow[t]{2}{*}{ Biodiversity ( $\%$, ranks) } & Environmental quality & 60.1 & 62.2 & 50.0 & 56.5 \\
\hline & Biodiversity and habitat & $84.1 / 105$ & $94.3 / 22$ & $64.7 / 105$ & $88.4 / 49$ \\
\hline \multirow[t]{5}{*}{ MPAs } & No-take areas, $\mathrm{km}^{2}($ mean $\pm \mathrm{SD})$ & $13.6 \pm 9.8$ & $8.7 \pm 16.8$ & $19.7 \pm 13.9$ & $479.0 \pm 823.6$ \\
\hline & No-take areas, $\mathrm{km}^{2}$ (total) & 54.3 & 121.6 & 84.6 & 1437.0 \\
\hline & No-take area as $\%$ reef area & 8.6 & 1.9 & 0.5 & 6.4 \\
\hline & Mean age of MPAs, yr & $31.6 \pm 9.5(9)$ & $17.4 \pm 10.4(19)$ & $10.2 \pm 4.4(5)$ & $20.0 \pm 18.9(4)$ \\
\hline & Mean age of no-take areas, yr & $35.0 \pm 8.7(4)$ & $19.3 \pm 11.6(14)$ & $10.5 \pm 5.0(4)$ & $11.7 \pm 11.0(3)$ \\
\hline
\end{tabular}

\footnotetext{
National wealth rank is extracted from World Bank wealth ranking of nations for either 2011 or 2015 when 2011 data not available.

*Access to knowledge and information is sourced from Social Progress Index.

${ }^{\S}$ Fisheries information extracted from (Burke et al. 2011, Teh et al. 2013). Artisanal fishery is fishing mostly done by men and is for both food and income, whereas subsistence fishery is for food and is dominated by women in most countries (Pauly 2007).
}

Committees, respectively. Legal jurisdictions were often being discussed and established but less seldom implemented or strongly enforced, which made it difficult to evaluate communities by their variable adherence to legal or informal justice procedures.

\section{FIELD METHODS}

\section{Field interviews}

Community-level variables were the means and variances resulting from face-to-face interviews of 10 to 30 individuals per landing site. A total of 1849 interviews were completed in the 89 landing sites. Individual resource users were chosen through a structured and randomized process whereby landing site leaders were consulted and a list of resource users and their primary gear was obtained. From the proportion of people using each fishing gear, specific interviewees were chosen randomly to obtain a stratified (gear type) random design. During the project-planning meeting, the landing site leader provided the names of all fishers by gear type, and researchers targeted a minimum of $30 \%$ of total fishers per site and by gear. Proportional sampling with respect to number of fishers and gear type was followed in most sites except in marina and reef where one gear type was dominant.

A standard questionnaire was used in all the fish landing sites and reported in a previous publication (McClanahan and Abunge 2016). The questionnaire assessed the user's perception of six basic management restrictions and who benefits from them. Interviewees were asked about each of the specific management restrictions and how they were perceived in terms of their benefits and sustainability. Each restriction was addressed separately (Appendix 1). The respondents rated their support, and we coded them from -2 to +2 values, the lowest and highest values being that they totally disagreed or agreed, respectively, with the statement about sustainability. "Don't know" responses were not included in the analyses. These coded responses of -2 to +2 were normalized to a positive 1 to 5 scale by adding 3 to all values for the purposes of statistical analysis. 
Questions about who would benefit the most from each of the 6 management restrictions and how the fisheries could be improved followed. Beneficiaries included individual resource users, their communities, and the national government, and respondents marked a point on a continuous 1 to 10 scale to estimate the benefit of each restriction, 10 being the maximum benefit (Appendixes 1 and 2). Differences between the estimated benefits to each beneficiary were calculated and explored to determine a best measure of social disparity. The average difference between national government and community and self-benefits was chosen, and the following formula used.

Disparity $=($ benefit government - benefit community $)+($ benefit government - benefit self) / 2

Socioeconomic characteristics of the fishing communities that might influence these responses were measured by standard socioeconomic questions reported in previous studies (Appendix 2; McClanahan et al. 2009a, 2012). These included the 10 variables, of which 8 were demographic and economic including number of jobs, years in occupation, residency, education, age, expenditures, material style of life (MSL; = physical capital), and household size. Two variables measured involvement in community organizations as membership in either fishing or conservation groups. MSL questions on house type and possessions were based on a principle component analysis (PCA) of the presence or absence of household items (Cinner and Pollnac 2004). Community averages were based on those individuals that answered all questions.

\section{Data analyses}

Responses to the previous questions were evaluated for withinand between-community differences in variations. Prior to statistical tests, response metrics were tested for normality using the Shapiro-Wilk $W$ test. Transformations were explored; $\log _{10}$ transformations were used for between-community data, and logit transformations for coefficient of variation (COV; \%) data. Both within- and between-community data sets did not meet the assumptions of normality, but within-community data weakly satisfied these assumptions; hence, nonparametric methods were used to test for significance.

The pairwise physical distances between communities were calculated using ArcGIS software (version 10.2.2; ESRI Inc., CA, USA). We took the GPS coordinates with handheld GPS receivers while visiting the landing sites. These coordinates were used to make a shape file using the World Mercator 1984 projection coordinate reference system. From this shape file, pairwise distances were calculated, obtained in ascending order for each site pair, and the shortest paired distance was used to establish the nearest neighbor. Tests for clustering in the spatial variation of the mean perceived benefits used the Moran's I index for withincommunity variation and between-community distances.

The COV $(\%=$ standard deviation $/$ mean perceived benefit $\times 100)$ of the normalized (adding a constant to eliminate negative numbers) response to benefits for each and all restrictions combined at each landing site was the within-community metric of variation. Between-community variation was calculated as the absolute difference between the same restriction responses for nearest-neighbor communities. This distance was used to evaluate the variation between communities for each fisheries restriction.
National within-community estimates were based on means of means and, therefore, were appropriate for parametric statistics. Intercommunity values were not means of means. Therefore, Wilcoxon/Kruskal-Wallis nonparametric tests and post hoc Dunn's test with Bonferroni adjustments for multiple comparisons were used. Transforming and normalizing the intraand intercommunity data allowed testing for significance of the interactions between nations and restrictions. Maps of the withinand between-community variation used $z$ scores of the within and nearest-neighbor distances to visualize the spatial distribution of variability among the six management restrictions, variability being a proxy for community agreement and disagreement.

Within- and between-community variations were also tested for associations with the 10 socioeconomic variables (Appendix 3) using a stepwise forward logistic regression procedure for each country and all countries combined. A PCA of the six management restrictions was done to ordinate the within- and between-community variation of all communities in all countries along these six axes of restriction variation. Key country-level economic descriptor vectors were included as supplementary variables to examine the relationships with the variability in each restriction. All statistics were performed using JMP version 13.0 statistical software (Sall et al. 2001) and R (R Development Core Team 2015) using the FactomineR package (Josse and Husson 2016) and visualized using the factoextra package (Kassambara and Mundt 2016).

\section{RESULTS}

\section{Spatial distribution of mean perceived benefits}

Mapping of the mean perceptions of the benefits of all restrictions combined indicates that Kenya and Tanzania had the highest variation or broadscale disagreements about benefits (Fig. 1). For example, in northern Kenya, adjacent communities were among the most and least positive about restrictions. Communities near the Mafia and Mtwara MPAs in Tanzania were among the least positive clusters as were some communities near the Dar es Salaam Reserve. In Madagascar and Mozambique, there were many communities with intermediate, but none with low, scaling.

\section{Comparing within- and between-community variation}

When evaluating all restrictions combined, all factors of nation and restriction were statistically significant for within- and between-community variation (Table 5). When tested for differences between nation and restriction type, withincommunity variation displayed larger differences than betweencommunity variation. Nation was the largest source of withincommunity variation, followed by restriction and, finally, their interaction. Differences in between-community variation differed significantly by nation, restriction, and their interaction, but all factors were weak (i.e., $F<3.5$ ).

\section{Patterns of within-community variation}

Within-community variation declined strongly with an increase in the mean perceptions of restriction benefits for all four countries (Fig. 2a). Kenya, Tanzania, and Mozambique all had strong relationships $\left(R^{2}>0.90\right)$ between mean benefits and within-community variation. Madagascar had a poorer fit $\left(R^{2}=\right.$ 0.47), but, because few communities scaled benefits lowly, the range of responses was low. 
Table 5. Tests of differences in pooled restriction variation by a two-factor ANOVA based on transformed data. The strengths of variation and possible interactions between within- and betweencommunity variation were tested. Within-community variation compared individuals within a community. Between-community variation used nearest-neighbor communities, and results are presented as the percentage of the maximum possible distance. Test of significance used log-transformed and logit-percenttransformed data for between community and within community, respectively. COV, coefficient of variation; SEM, standard error of the mean.

\begin{tabular}{lccccc}
\hline \hline & \multicolumn{2}{c}{$\begin{array}{c}\text { Within-community } \\
\text { COV, } \%\end{array}$} & & \multicolumn{2}{c}{$\begin{array}{c}\text { Between-community } \% \\
\text { of maximum }\end{array}$} \\
\cline { 2 - 3 } \cline { 5 - 6 } Variables & Means & SEM & & Means & SEM \\
\hline Kenya & 43.12 & 1.48 & & 17.00 & 1.26 \\
Tanzania & 47.58 & 1.59 & & 18.36 & 1.30 \\
Mozambique & 27.48 & 1.89 & & 14.76 & 1.69 \\
Madagascar & 24.26 & 1.63 & & 10.31 & 1.43 \\
Two-factor ANOVA & $F$ ratio & $P$ value & & $F$ ratio & $P$ value \\
Nation & 41.76 & 0.0001 & & 3.45 & 0.017 \\
Restriction & 20.93 & 0.0001 & & 2.29 & 0.046 \\
Nation $\times$ restriction & 3.11 & 0.0001 & & 1.67 & 0.056 \\
\hline
\end{tabular}

Fig. 2. Relationship between the scaling of the perceived benefits at landing sites and (a) within-community variation and (b) nearest-neighbor between-community distances for all six restrictions pooled. COV, coefficent of variation.
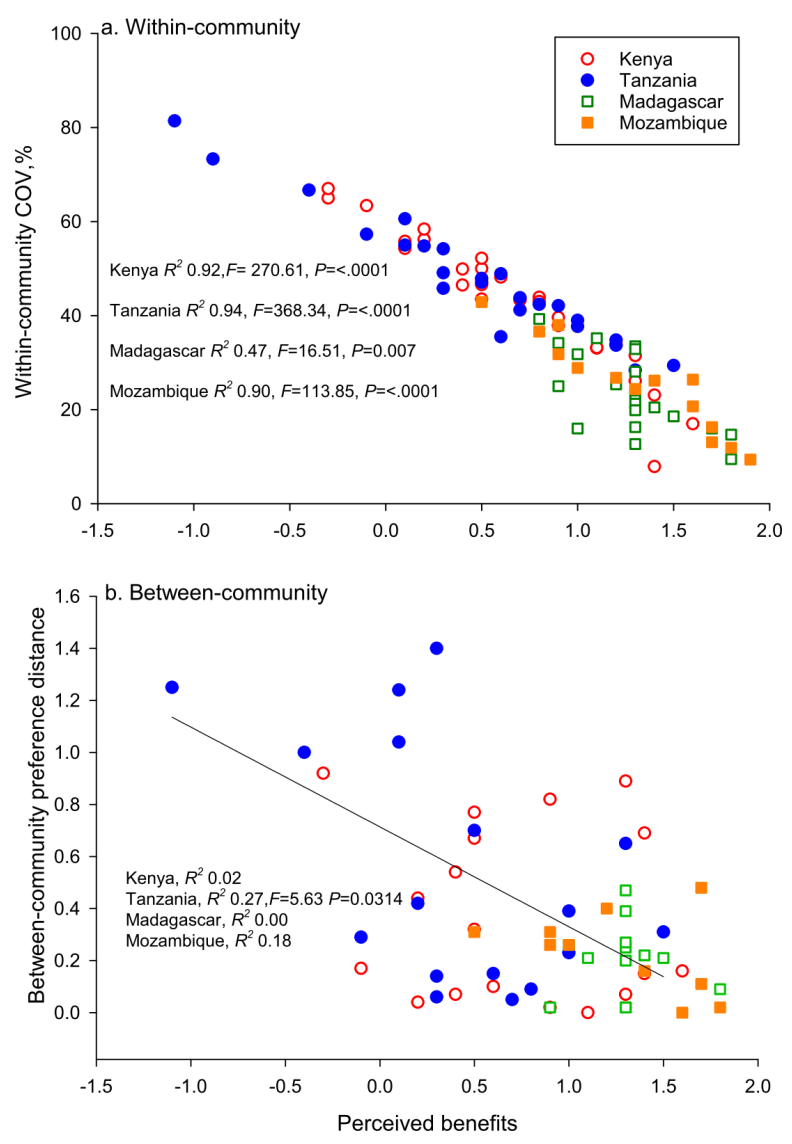

Within-community COV was $64 \%$ for Kenya, $48 \%$ for Tanzania, and $22 \%$ for both Madagascar and Mozambique (Fig. 3). Within-community variations in countries were distinguished primarily by four restrictions, namely, species selection, closed seasons, protected areas, and closed areas (Fig. 4a). Variations were primarily positively associated with the country descriptors of per capita income, mobile phone ownership, and advanced education (Table 4). The smallest variation was associated with size and gear restrictions, which were weakly negatively associated with a nation's GINI coefficient and government expenditures as percentage of GDP.

Fig. 3. Within-community coefficient of variation (COV, $\%$; means + standard deviation) of each landing site in the four studied countries based on pooling all six management restrictions. The mean for the whole country for all landing sites is also presented. Countries and sites are arranged from north to south.

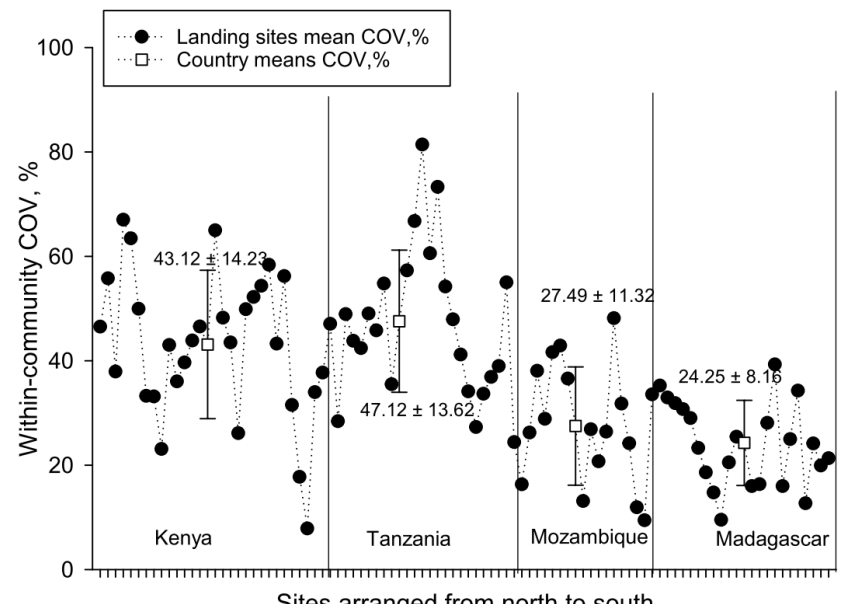

Differences between nations and restrictions were influenced by the proposed restriction strength (Table 6). For example, gear restrictions had the lowest variation and did not vary by country. Minimum size of fish had the second lowest variation, and only Tanzania differed by having higher variation than the other nations. Two response groups were produced by protected areas, seasonal closures, closed areas, and species restrictions, namely, a high-variation group of Kenya and Tanzania and a lowvariation group of Madagascar and Mozambique.

Perceptions of benefits and fairness, or the perceived disparity between benefits to government versus those accrued to individuals and communities, were stronger than the 10 socioeconomic indicators in predicting within-community variation. All variables combined predicted $53 \%$ of the variance (Table 7). Variation declined strongly as the perceived benefit of the restriction and the total number of jobs of the respondent's household increased. Membership in fishing organizations was significant but weaker, and education and wealth, i.e., expenditures and MSL, did not reduce variation. Residence time was also predicted to be negatively associated with community variation but positively associated in Mozambique and not significant in the other countries. 
Table 6. Test of within-community variation results (coefficient of variation, $\%$ mean + standard deviation) of Kruskal-Wallis test and post hoc Dunn's test with Bonferroni adjustment for multiple comparisons. Numbers $(1,2,3)$ distinguish significance between countries, and capital letters (A, B, C) distinguish management restrictions within countries. Values followed with the same numbers in parentheses are not significantly different from each other for comparison of nations. Values followed with the same letters are not significantly different from each other for comparison of management restrictions. Bolded values are the significant $\mathrm{P}$ values. Countries are listed from most to least wealthy. Management restrictions are arranged from least to most access restrictions.

\begin{tabular}{|c|c|c|c|c|c|c|c|c|c|}
\hline Variables & $\begin{array}{l}\text { Minimum fish } \\
\text { size }\end{array}$ & $\begin{array}{c}\text { Gear } \\
\text { restriction }\end{array}$ & $\begin{array}{c}\text { Species } \\
\text { selection }\end{array}$ & $\begin{array}{l}\text { Closed } \\
\text { seasons }\end{array}$ & $\begin{array}{c}\text { Protected } \\
\text { areas }\end{array}$ & Closed areas & $\begin{array}{l}\text { Pooled } \\
\text { restrictions }\end{array}$ & $\begin{array}{c}\text { Chi- } \\
\text { square }\end{array}$ & $\begin{array}{l}P>\text { chi }- \\
\text { square }\end{array}$ \\
\hline Kenya & $\begin{array}{c}22.86 \pm 16.18 \\
B(1)\end{array}$ & $\begin{array}{c}20.05 \pm 15.88 \\
B(1)\end{array}$ & $\begin{array}{c}49.83 \pm 19.25 \\
A(1,2)\end{array}$ & $\begin{array}{c}58.16 \pm 17.30 \\
A(1)\end{array}$ & $\begin{array}{c}49.93 \pm 24.31 \\
A(1)\end{array}$ & $\begin{array}{c}57.90 \pm 28.99 \\
A(1)\end{array}$ & $43.12 \pm 12.23$ & 63.64 & 0.0001 \\
\hline Tanzania & $\begin{array}{c}39.10 \pm 20.16 \\
B C(2)\end{array}$ & $\begin{array}{c}26.06 \pm 16.99 \\
B(1)\end{array}$ & $\begin{array}{c}62.79 \pm 20.35 \\
A(1)\end{array}$ & $\begin{array}{c}58.53 \pm 14.25 \\
A(1)\end{array}$ & $\begin{array}{c}48.44 \pm 15.68 \\
A C(1)\end{array}$ & $\begin{array}{c}50.56 \pm 17.72 \\
A C(1)\end{array}$ & $\begin{array}{c}47.58 \pm 13.62 \\
(1)\end{array}$ & 48.03 & 0.0001 \\
\hline Mozambique & $\begin{array}{c}21.44 \pm 14.85 \\
\mathrm{~A} B(1)\end{array}$ & $\begin{array}{c}17.56 \pm 16.38 \\
\mathrm{~A} B(1)\end{array}$ & $\begin{array}{c}37.54 \pm 20.57 \\
B(2)\end{array}$ & $\begin{array}{c}31.43 \pm 25.46 \\
A B(2)\end{array}$ & $\begin{array}{c}11.67 \pm 12.09 \\
A(2)\end{array}$ & $\begin{array}{c}45.30 \pm 32.23 \\
B(1,2)\end{array}$ & $\begin{array}{c}27.49 \pm 11.32 \\
\text { (2) }\end{array}$ & 22.11 & 0.0005 \\
\hline Madagascar & $\begin{array}{c}22.20 \pm 20.47 \\
A(1)\end{array}$ & $\begin{array}{c}21.99 \pm 17.44 \\
A(1)\end{array}$ & $\begin{array}{c}37.54 \pm 16.09 \\
B(2)\end{array}$ & $\begin{array}{c}22.67 \pm 15.52 \\
\mathrm{~A} B(2)\end{array}$ & $\begin{array}{c}15.47 \pm 16.09 \\
A(2)\end{array}$ & $\begin{array}{c}25.43 \pm 12.54 \\
A B(2)\end{array}$ & $\begin{array}{c}24.26 \pm 8.16 \\
\text { (2) }\end{array}$ & 21.29 & 0.0007 \\
\hline Regional mean & $26.67 \pm 18.66$ & $21.65 \pm 17.47$ & $47.93 \pm 21.38$ & $44.44 \pm 23.96$ & $33.86 \pm 25.28$ & $45.54 \pm 26.56$ & $36.68 \pm 15.64$ & & \\
\hline Chi-square & 12.24 & 2.67 & 19.47 & 40.31 & 47.62 & 20.79 & 40.24 & & \\
\hline$P>$ chi-square & 0.007 & 0.45 & 0.0002 & 0.0001 & 0.0001 & 0.0001 & 0.0001 & & \\
\hline
\end{tabular}

Fig. 4. Principal component analyses (PCA) of the fishing communities in the four nations as distributed along the (a) within-community and (b) between-community variation of the six management restrictions. Country socioeconomic variables are overlain as supplementary variables to the PCA analysis.

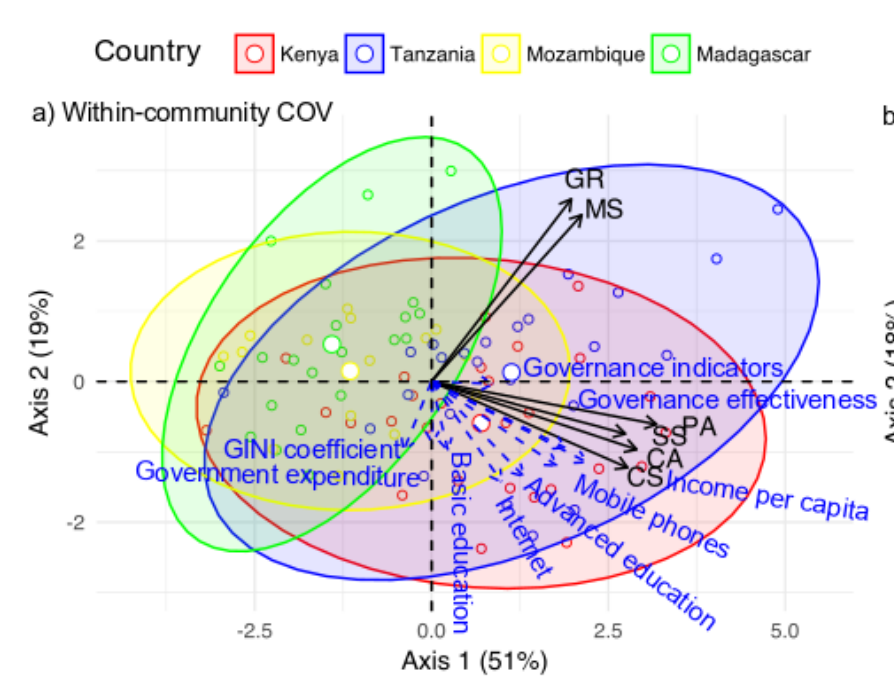
MS: Minimum fish size
GR: Gear restriction
SS: Species selection CS: Closed season
PA: Protected area
CA: Closed area

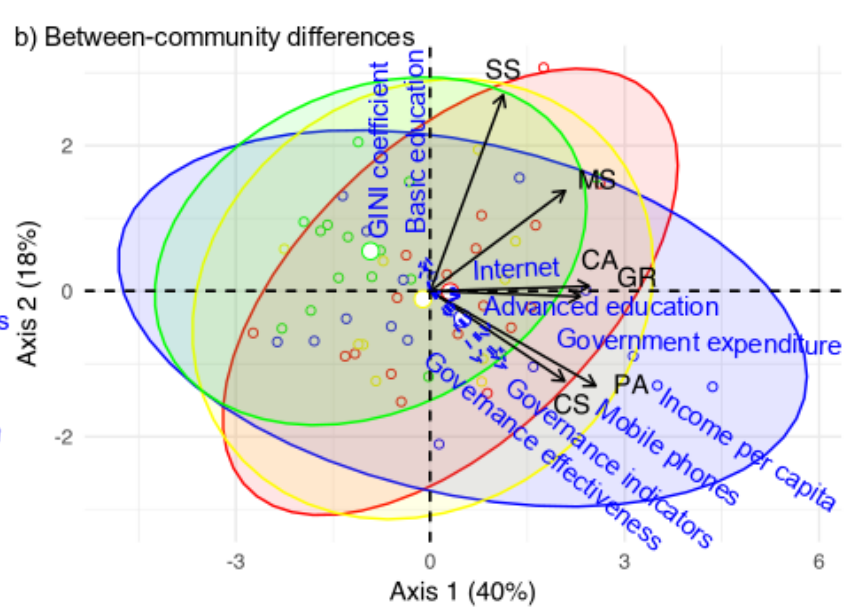

\section{Patterns of between-community variation}

Overall, the four countries had largely similar betweencommunity variation (Table 8). Nevertheless, specific restrictions produced more between-country variation, and these were variably associated with country-level socioeconomic associations (Fig. 4b). Madagascar's normalized between-community variation $(\mathrm{COV}, \%)$ was about 20 percentage points higher than the other countries and influenced by the specific restriction. Tanzania also had a high spread in between-community differences for specific restrictions, with particularly high differences for protected and closed area restrictions. This contrasts with Madagascar where species and minimum size at capture restrictions were the most variable. In strong contrast to within-community variation, between-community variation was not associated with the mean perceived benefits of restrictions in Kenya, Madagascar, and Mozambique (Fig. 2b). There was, however, a wide spread and a weak relationship in the perceived benefits in Tanzania $\left(R^{2}=0.27\right)$.

Between-community had low variation in minimum size and gear restrictions that did not differ between the four countries (Table 8). Species selection restrictions had the highest variation with no differences between countries. High strength restrictions of closed seasons, protected areas, and closed areas had high variation and statistical differences between nations. Madagascar had low variation, and Mozambique was not different from the higher variation in Kenya and Tanzania. Consequently, when comparing 
Table 7. Results of stepwise regression analysis evaluating socioeconomic variables associated with between- and within-community variations. The variables are arranged from strongest to weakest association. Results presented are (a) all countries using pooled data, (b) Kenya, (c) Tanzania, (d) Mozambique, and (e) Madagascar. Signs of the tratio indicate the direction of association with the variation.

\begin{tabular}{|c|c|c|c|c|c|c|c|c|c|}
\hline \multicolumn{5}{|c|}{ Within community } & \multicolumn{5}{|c|}{ Between community } \\
\hline Variables & $t$ ratio & $F$ ratio & $P$ value & $R^{2}$ & Variables & $t$ ratio & $F$ ratio & $P$ value & $R^{2}$ \\
\hline a. All countries pooled & & 402.39 & $<0.0001$ & 0.53 & & & 42.58 & $<0.0001$ & 0.13 \\
\hline Perceived benefits & -19.76 & 390.59 & 0.0001 & & Total jobs & -6.92 & 47.87 & 0.0001 & \\
\hline Perceived disparity & +18.32 & 335.79 & 0.0001 & & Perceived benefits & -5.11 & 26.15 & 0.0001 & \\
\hline Total jobs & -15.48 & 238.66 & 0.0001 & & Perceived disparity & +3.75 & 14.07 & 0.0002 & \\
\hline Years in occupation & +4.40 & 19.38 & 0.0001 & & Years in occupation & +3.50 & 12.27 & 0.0005 & \\
\hline Social capital-fishing organization & -3.32 & 10.99 & 0.0009 & & & & & & \\
\hline b. Kenya & & 399.29 & $<0.0001$ & 0.53 & & & 26.97 & $<0.0001$ & 0.07 \\
\hline Perceived benefits & -20.33 & 413.25 & 0.0001 & & Perceived disparity & +8.76 & 76.80 & 0.0001 & \\
\hline Perceived disparity & +18.46 & 340.93 & 0.0001 & & Fortnight expenditures & +2.07 & 4.28 & 0.039 & \\
\hline Total jobs & -15.01 & 225.17 & 0.0001 & & & & & & \\
\hline Social capital-fishing organization & -2.79 & 7.78 & 0.0053 & & & & & & \\
\hline Years of education & +0.69 & 0.48 & 0.49 & & & & & & \\
\hline c. Tanzania & & 400.82 & $<0.0001$ & 0.47 & & & 21.51 & $<0.0001$ & 0.10 \\
\hline Perceived disparity & +20.06 & 402.29 & 0.0001 & & Perceived disparity & +5.61 & 31.44 & 0.0001 & \\
\hline Perceived benefits & -19.90 & 395.98 & 0.0001 & & Perceived benefits & -5.30 & 28.08 & 0.0001 & \\
\hline Years in occupation & +3.48 & 12.12 & 0.0005 & & Years in occupation & +2.99 & 8.92 & 0.0029 & \\
\hline Household size & -3.46 & 11.95 & 0.0006 & & Years in education & -1.28 & 1.64 & 0.20 & \\
\hline d. Mozambique & & 234.27 & $<0.0001$ & 0.44 & & & 0.75 & 0.47 & 0.00 \\
\hline Perceived benefits & -30.84 & 951.34 & 0.0001 & & Material style of life & -1.14 & 1.29 & 0.26 & \\
\hline Total jobs & -16.03 & 256.80 & 0.0001 & & Years in residence & -0.52 & 0.28 & 0.60 & \\
\hline Years in residence & +3.27 & 10.73 & 0.0011 & & & & & & \\
\hline Material style of life & +1.53 & 2.34 & 0.13 & & & & & & \\
\hline Fortnight expenditure & +1.13 & 1.28 & 0.26 & & & & & & \\
\hline $\begin{array}{l}\text { Social capital-community } \\
\text { organization }\end{array}$ & -0.85 & 0.72 & 0.40 & & & & & & \\
\hline e. Madagascar & & 399.29 & $<0.0001$ & 0.53 & & & 42.39 & $<0.0001$ & 0.13 \\
\hline Perceived benefits & -20.39 & 415.62 & 0.0001 & & Total jobs & -6.55 & 42.85 & 0.0001 & \\
\hline Perceived disparity & +18.38 & 337.91 & 0.0001 & & Perceived benefits & -5.78 & 33.46 & 0.0001 & \\
\hline Total jobs & -14.93 & 223.02 & 0.0001 & & Perceived disparity & +4.28 & 18.28 & 0.0001 & \\
\hline Social capital-fishing organization & -2.81 & 7.87 & 0.0051 & & Material style of life & +0.10 & 0.01 & 0.922 & \\
\hline Household size & -0.34 & 0.11 & 0.73 & & & & & & \\
\hline
\end{tabular}

all restrictions, Tanzania and Madagascar had significant differences between restrictions, whereas Kenya and Mozambique did not. Closed seasons in Madagascar had the lowest betweencommunity variation of all restrictions and nations.

Perceptions of benefits, fairness, and the 10 socioeconomic indicators were weakly associated with between-community variation $\left(R^{2}<0.13\right.$; Table 7$)$. Variation increased with the perceived disparity of the benefits and years in the fishing occupation. Relationships with perceptions of benefits and disparity, jobs, and occupation metrics were weak and of similar strength. Variation declined as the total number of jobs and the perceived benefits of restrictions increased. In Kenya, variation was not associated with perceived benefits and years in occupation. In Mozambique, variation was not significantly associated with any of the studied factors.

\section{Locations of potential conflict and cooperation}

There was significant spatial clustering of mean perceived benefits when all restrictions were combined and for some specific restrictions (Table 9a). Kenya, Madagascar, and Mozambique had significant but low clustering strengths (Moran's I 0.45-0.50), whereas Tanzania had stronger clustering (Moran's $\mathrm{I}=0.82$ ). In Tanzania, the clustering was significant for minimum size, gear restrictions, species selection, and closed seasons but not for protected areas and closures. Madagascar showed the same by-restriction clustering patterns as Tanzania, but the scaling of benefits of protected areas was also significantly clustered. In contrast, Kenya only showed significant spatial clustering associated with protected areas and closure restrictions, and Mozambique only for closures. Within-community variation also displayed significant spatial clustering for all restrictions combined and followed similar patterns to mean benefit values for specific restrictions and by country (Table $9 b$ ).

Between-community variation in some specific restrictions displayed weaker spatial clustering (Table 9c); Kenya had none, and Tanzania had only between-community spatial clustering for gear restrictions. Mozambique and Madagascar had the most between-community clustering and significant spatial clustering 
Fig. 5. Plotting of management restriction preference and physical distances by country for all the management restrictions. Preference distances are based on betweencommunity differences on their rating of the management restriction ( 1 to 5 adjusted from -2 to +2 by adding 3 ).
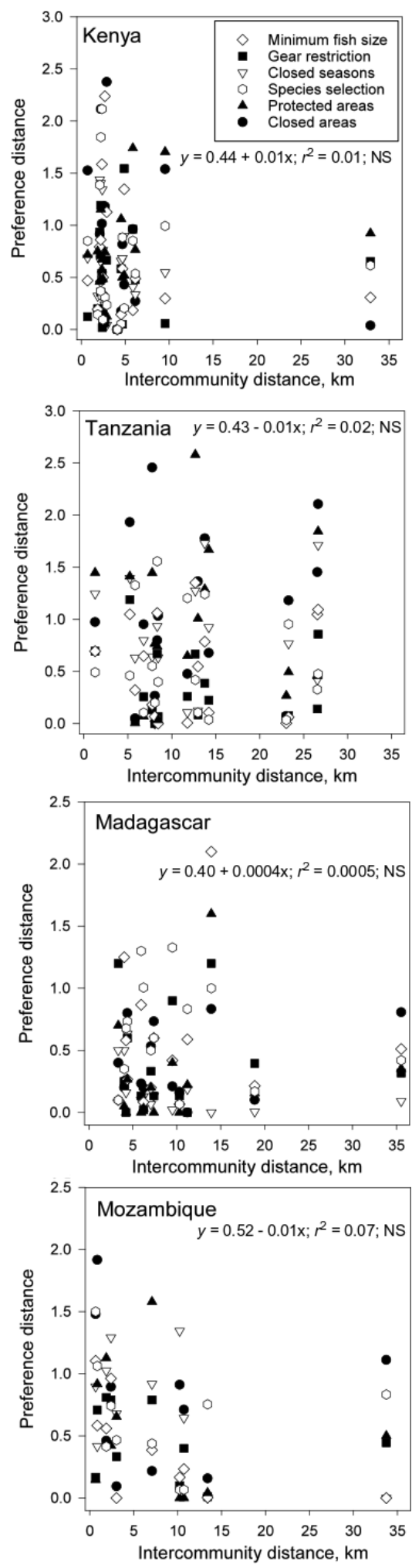

for all restrictions combined, as well as clustering of minimum size, species, and closed and protected area restrictions. Scatter plots and regression statistics indicate that despite the abovementioned clustering, there were no significant linear relationships between the physical distance between communities and the differences in the scaling of benefits within nations (Fig. 5).

Maps of the distribution of the within- and between-community variation in restriction preferences identify a number of potential areas of agreement and disagreement (Appendix 4). For example, preferences for the minimum size of fish exhibits high withincommunity agreement but with potential neighbor conflict areas in northern and southern Kenya and Tanzania, as well as northeast Madagascar (Fig. 6). Similarly, gear displayed high within-community agreement. However, where there were areas of disagreement, they aligned with size-restriction preferences. Northern Mozambique also had potential conflict areas in gear preferences. There was less within-community agreement on species selection, and some high-agreement communities had potential disagreements with neighbors in the border regions of Kenya and Tanzania, as well as southwest Madagascar (Fig. 7). Closed season had a moderate potential for neighbor-community disagreements in northern Kenya, southern Tanzania, and northern Mozambique. Protected areas had the most potential for disagreement ranging from northern Kenya to northern Mozambique and also southwest Madagascar. Closed area responses were similar to protected areas but with less potential for disagreement in southwest Madagascar.

\section{DISCUSSION}

Perceptions of management restriction benefits are variable in this region and influenced by the national context, type of restriction, and a number of interrelated demographic characteristics. We confirmed that within-community variation declined strongly with perceived benefit and was considerably less than between-community variation. This unsurprising finding supports the homophily proposition that perceptions are more similar when people stay and interact together (McPherson et al. 2001, Ostrom 2010). More surprising was that within-community similarity did differ with the restriction type, suggesting limits to the similarities of cohabitant views when faced with potentially lower net individual benefits. Consequently, conflicts are possible over specific restrictions and may reflect each individual's views of the costs/benefits of specific restrictions, even within homogenous communities. Moreover, within-community variability was lowest in the low population density, poorer, and weak national governance countries of Madagascar and Mozambique. These two countries also had less restriction experience in terms of the ubiquity, ages, and effective national governance and compliance of protected areas and fisheries closures. Context and experiences combined with isolation, poverty, lower advanced education, reduced access to communication technologies, and fewer interactions with media and government were likely to promote stronger local norms and lower community variability (Table 4, Fig. 4a).

\section{Sources of variation}

Greater individuality within communities is expected where people are less isolated and have more wealth, education, occupational diversity, and information available through either 
Fig. 6.

Maps of the distributions of the within- and between-community variation for the capture size of fish and gear restrictions. Colors indicate the level of variation between communities based on $\mathrm{z}$ scores of the intercommunity variation. The size of the circles indicates the within-community level of agreement with restriction, i.e., larger circles indicate greater agreement with benefits of restrictions. SD, standard deviation.
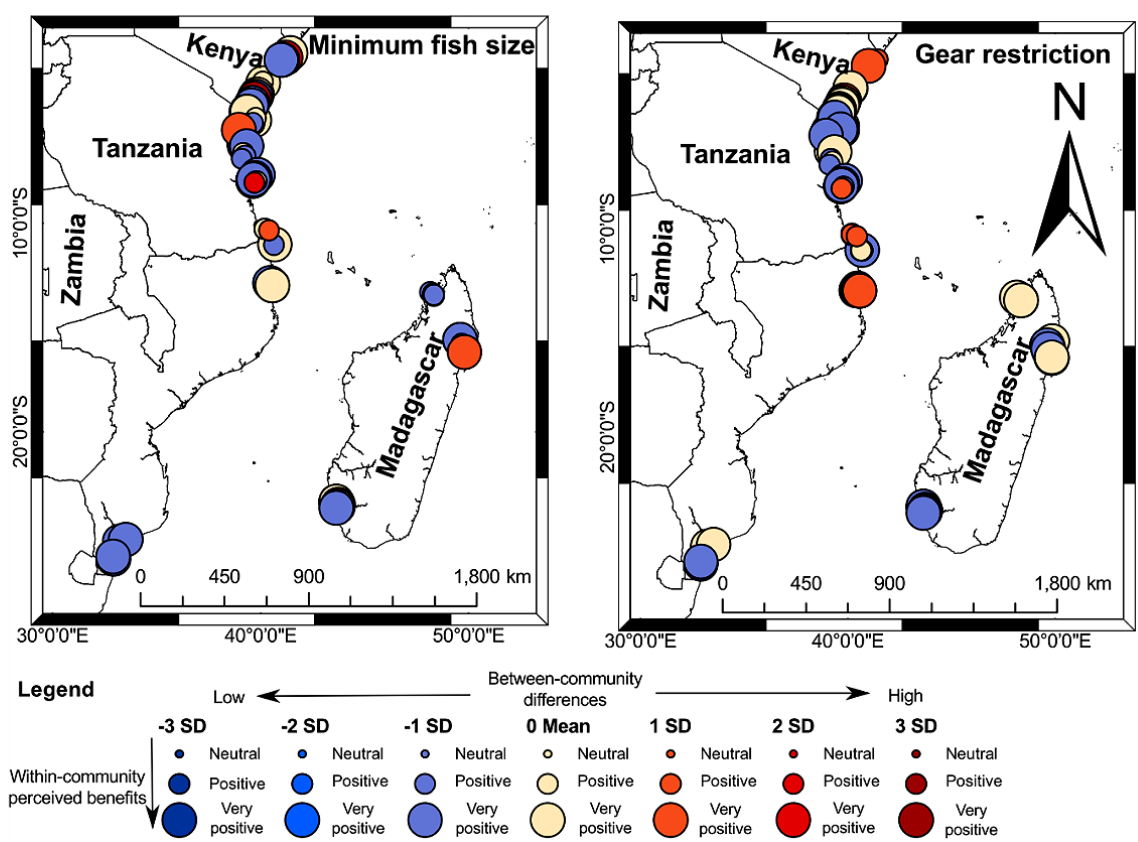

\section{Fig. 7.}

Maps of the distributions of the within- and between-community variation for the species selection, closed seasons, protected areas, and closed areas. Colors indicate the level of variation between communities based on $\mathrm{z}$ scores of the intercommunity variation. The size of the circles indicates the within-community level of agreement with restriction, i.e., larger circles indicate greater agreement with benefits of restrictions.

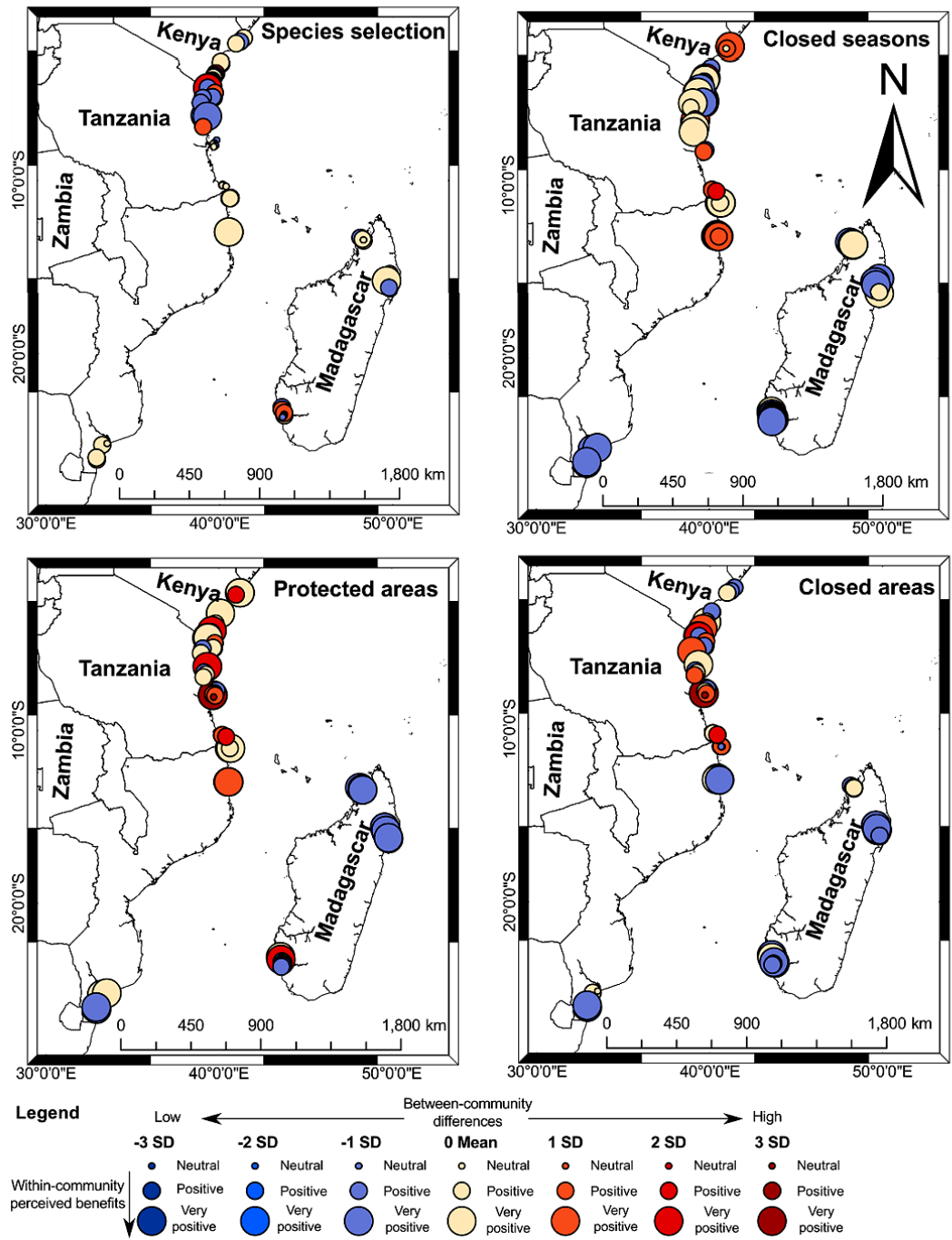


Table 8. Comparisons of between-community variation in management preferences by country (a, mean distance, + standard deviation; b, coefficients of variation, \%) based on Kruskal-Wallis test and post hoc Dunn's test with Bonferroni adjustment for multiple comparisons. Numbers $(1,2,3)$ distinguish significance between countries, and captial letters (A, B, C) distinguish management restrictions within countries. Values followed with the same numbers in parentheses are not significantly different from each other for comparison of nations. Values followed with the same letters are not significantly different from each other for comparison of management restrictions. Bolded values are the significant $\mathrm{P}$ values. Countries are arranged from most to least wealthy. Management options are arranged from least to most restrictive.

\begin{tabular}{|c|c|c|c|c|c|c|c|c|c|}
\hline \multicolumn{10}{|c|}{ a. Mean difference } \\
\hline Variables & $\begin{array}{l}\text { Minimum fish } \\
\text { size }\end{array}$ & $\begin{array}{c}\text { Gear } \\
\text { restriction }\end{array}$ & $\begin{array}{l}\text { Species } \\
\text { selection }\end{array}$ & $\begin{array}{l}\text { Closed } \\
\text { seasons }\end{array}$ & $\begin{array}{l}\text { Protected } \\
\text { areas }\end{array}$ & Closed areas & $\begin{array}{c}\text { Pooled } \\
\text { restrictions }\end{array}$ & $\begin{array}{l}\text { Chi- } \\
\text { square }\end{array}$ & $\begin{array}{l}P>\text { chi- } \\
\text { square }\end{array}$ \\
\hline Kenya & $\begin{array}{c}0.66 \pm 0.58 A \\
\text { (1) }\end{array}$ & $\begin{array}{c}0.47 \pm 0.46 A \\
\text { (1) }\end{array}$ & $\begin{array}{c}0.66 \pm 0.61 A \\
\text { (1) }\end{array}$ & $\begin{array}{c}0.74 \pm 0.54 A \\
\text { (2) }\end{array}$ & $\begin{array}{c}0.74 \pm 0.45 A \\
\text { (2) }\end{array}$ & $\begin{array}{c}0.81 \pm 0.72 A \\
(1,2)\end{array}$ & $\begin{array}{c}0.68 \pm 0.30 \\
\text { (2) }\end{array}$ & 4.29 & 0.51 \\
\hline Tanzania & $\begin{array}{c}0.53 \pm 0.47 \\
A B(1)\end{array}$ & $\begin{array}{c}0.34 \pm 0.35 \mathrm{~A} \\
\text { (1) }\end{array}$ & $\begin{array}{c}0.58 \pm 0.49 \\
A B(1)\end{array}$ & $\begin{array}{c}0.79 \pm 0.56 \\
A B(2)\end{array}$ & $\begin{array}{c}0.95 \pm 0.72 \\
A B(2)\end{array}$ & $\begin{array}{c}1.21 \pm 0.84 B \\
\text { (1) }\end{array}$ & $\begin{array}{c}0.73 \pm 0.42 \\
(2)\end{array}$ & 16.61 & 0.005 \\
\hline Mozambique & $\begin{array}{c}0.39 \pm 0.39 A \\
\text { (1) }\end{array}$ & $\begin{array}{c}0.46 \pm 0.31 \mathrm{~A} \\
\text { (1) }\end{array}$ & $\begin{array}{c}0.63 \pm 0.44 A \\
\text { (1) }\end{array}$ & $\begin{array}{c}0.79 \pm 0.47 A \\
(1,2)\end{array}$ & $\begin{array}{c}0.54 \pm 0.54 A \\
(1,2)\end{array}$ & $\begin{array}{c}0.78 \pm 0.59 A \\
(1,2)\end{array}$ & $\begin{array}{c}0.59 \pm 0.27 \\
(1,2)\end{array}$ & 4.68 & 0.46 \\
\hline Madagascar & $\begin{array}{c}0.56 \pm 0.55 \\
A B(1)\end{array}$ & $\begin{array}{c}0.40 \pm 0.42 \\
A B(1)\end{array}$ & $\begin{array}{c}0.65 \pm 0.41 B \\
\text { (1) }\end{array}$ & $\begin{array}{c}0.19 \pm 0.20 \mathrm{~A} \\
\text { (1) }\end{array}$ & $\begin{array}{c}0.28 \pm 0.43 \\
A B(1)\end{array}$ & $\begin{array}{c}0.39 \pm 0.29 \\
\mathrm{~A} B(2)\end{array}$ & $\begin{array}{c}0.41 \pm 0.24 \\
(1)\end{array}$ & 15.06 & 0.009 \\
\hline Regional mean & $0.56 \pm 0.51$ & $0.41 \pm 0.38$ & $0.63 \pm 0.50$ & $0.62 \pm 0.52$ & $0.66 \pm 0.60$ & $0.82 \pm 0.71$ & $0.62 \pm 0.34$ & & \\
\hline Chi-square & 1.69 & 1.12 & 0.48 & 12.94 & 13.00 & 9.00 & 8.74 & & \\
\hline$P>$ chi-square & 0.64 & 0.77 & 0.92 & 0.05 & 0.005 & 0.03 & 0.03 & & \\
\hline \multicolumn{10}{|c|}{ b. Coefficients of variation, $\%$} \\
\hline Variables & $\begin{array}{l}\text { Minimum fish } \\
\text { size }\end{array}$ & $\begin{array}{l}\text { Gear } \\
\text { restriction }\end{array}$ & $\begin{array}{l}\text { Species } \\
\text { selection }\end{array}$ & $\begin{array}{l}\text { Closed } \\
\text { seasons }\end{array}$ & $\begin{array}{l}\text { Protected } \\
\text { areas }\end{array}$ & Closed areas & $\begin{array}{l}\text { Country by- } \\
\text { restriction } \\
\text { average }\end{array}$ & $\begin{array}{l}\text { Pooled } \\
\text { restriction } \\
\text { average } \\
\end{array}$ & \\
\hline Kenya & 87.6 & 96.7 & 93.5 & 72.9 & 61.2 & 88.5 & 83.40 & 44.5 & \\
\hline Tanzania & 88.5 & 104.3 & 84.1 & 70.6 & 76.1 & 69.5 & 82.18 & 57.3 & \\
\hline Mozambique & 99.7 & 67.0 & 69.7 & 65.6 & 99.4 & 75.0 & 79.40 & 45.1 & \\
\hline \multirow{2}{*}{$\begin{array}{l}\text { Madagascar } \\
\text { Regional mean }\end{array}$} & 98.8 & 101.8 & 63.6 & 106.2 & 150.8 & 74.7 & 99.32 & 59.3 & \\
\hline & 91.9 & 93.7 & 78.8 & 84.3 & 90.3 & 86.7 & 86.1 & 55.1 & \\
\hline
\end{tabular}

the media or government. For example, a large study of trending media topics found that both personal and mass media trends followed wealth distributions, with some barriers and clustering created by differences in language and culture (Carrascosa et al. 2015). Despite the potential for greater information distribution in wealthy countries, spatial clustering of preferences was present in all countries. Within-community clustering was strongest when pooling all restrictions, but weaker patterns were observed for specific restrictions. Tanzania and Madagascar had the most spatial clustering for the low cost/benefit restrictions, such as size, gear, species, and seasonal restrictions, whereas Kenya had the most clustering for the high cost/benefit restrictions of closed and protected areas. Mozambique was more spatially uniform for specific restrictions and only clustered significantly when comparing the pooled restriction responses. Consequently, spatial variability and clustering of within-community preferences was restriction specific in some cases and, therefore, difficult to attribute solely to country-level statistics. This suggests nationallevel responses for specific restrictions within nations, possibly similar to the restraining effects of language and culture on the spread of media.

Intercommunity variation was high overall and exhibited small differences between nations, with somewhat higher variation in Madagascar than the three other countries. Consequently, the relative differences or inter/intracommunity ratios were higher in Madagascar and Mozambique. Consequently, individuals from a country with small within-community variation might sense stronger differences in restriction preferences when interacting with other communities in the nation. However, there was also higher within-community spatial clustering in Madagascar and Mozambique for the high individual cost/benefit restrictions, making conflicting perceptions less likely for some restrictions among neighboring communities. Therefore, less conflict would be expected in countries like Madagascar for restrictions that are distributed over limited spatial scales. On the other hand, Kenya and Tanzania had the potential for stronger conflicts within and between communities for some restrictions, but this depended on the restriction type.

Both scales of community variability increased with our proposed cost/benefit gradient, but more conservatively, there were two management restriction groupings: two low individual cost/ benefit restrictions of size and gear, and four higher individual cost/benefit restrictions of species selection, closed seasons, closed areas, and MPAs. Weaker differences for betweencommunity variation in size, gear, and species selection restrictions among nations support the proposition that perceptions are shared because of broadly acknowledged individual cost/benefit considerations. However, variation in 
Table 9. Moran's I statistic testing for spatial associations for (a) mean management restrictions responses and the variation attributable to (b) within-community and (c) between-community distances. Tests determine if the distributions in space are different from the null hypotheses of no significant spatial organization. Bolded numbers represent significant $\mathrm{P}$ values for each management restriction in each of the four western Indian Ocean countries: Kenya, Tanzania, Madagascar, and Mozambique.

\begin{tabular}{|c|c|c|c|c|c|c|}
\hline \multicolumn{7}{|c|}{ a. Within-community mean response } \\
\hline Metric & Country & $\begin{array}{l}\text { Moran's I } \\
\text { index }\end{array}$ & Expected & Variance & $z$ Score & $P$ value \\
\hline \multirow[t]{4}{*}{ Minimum fish size } & Kenya & -0.20 & -0.04 & 0.02 & -1.04 & 0.29 \\
\hline & Tanzania & 1.07 & -0.04 & 0.08 & 3.85 & 0.0001 \\
\hline & Mozambique & 0.36 & -0.07 & 0.06 & 1.70 & 0.08 \\
\hline & Madagascar & 0.46 & -0.05 & 0.03 & 2.84 & 0.004 \\
\hline \multirow[t]{4}{*}{ Gear restriction } & Kenya & 0.19 & -0.04 & 0.03 & 1.45 & 0.15 \\
\hline & Tanzania & 0.99 & -0.04 & 0.08 & 3.70 & 0.0002 \\
\hline & Mozambique & 0.04 & -0.07 & 0.07 & 0.42 & 0.67 \\
\hline & Madagascar & 0.35 & -0.05 & 0.03 & 2.49 & 0.01 \\
\hline \multirow[t]{4}{*}{ Species selection } & Kenya & 0.31 & -0.04 & 0.03 & 2.04 & 0.04 \\
\hline & Tanzania & 0.71 & -0.04 & 0.09 & 2.56 & 0.01 \\
\hline & Mozambique & 0.18 & -0.07 & 0.07 & 0.93 & 0.35 \\
\hline & Madagascar & 0.57 & -0.05 & 0.03 & 3.57 & 0.0003 \\
\hline \multirow[t]{4}{*}{ Closed seasons } & Kenya & 0.02 & -0.04 & 0.03 & 0.34 & 0.73 \\
\hline & Tanzania & 0.64 & -0.04 & 0.09 & 2.30 & 0.02 \\
\hline & Mozambique & -0.04 & -0.07 & 0.07 & 0.09 & 0.92 \\
\hline & Madagascar & 0.73 & -0.05 & 0.03 & 4.62 & 0.0001 \\
\hline \multirow[t]{4}{*}{ Protected areas } & Kenya & 0.46 & -0.04 & 0.03 & 2.88 & 0.004 \\
\hline & Tanzania & 0.33 & -0.04 & 0.08 & 1.29 & 0.19 \\
\hline & Mozambique & -0.03 & -0.07 & 0.07 & 0.13 & 0.89 \\
\hline & Madagascar & 0.96 & -0.05 & 0.03 & 5.62 & 0.0001 \\
\hline \multirow[t]{4}{*}{ Closed areas } & Kenya & 0.54 & -0.03 & 0.03 & 3.36 & 0.0001 \\
\hline & Tanzania & 0.07 & -0.04 & 0.08 & 0.40 & 0.68 \\
\hline & Mozambique & 0.51 & -0.07 & 0.07 & 2.09 & 0.04 \\
\hline & Madagascar & 0.15 & -0.05 & 0.03 & 1.12 & 0.26 \\
\hline \multirow[t]{4}{*}{ Pooled restrictions } & Kenya & 0.45 & -0.04 & 0.03 & 2.87 & 0.004 \\
\hline & Tanzania & 0.82 & -0.04 & 0.08 & 3.03 & 0.002 \\
\hline & Mozambique & 0.48 & -0.07 & 0.07 & 2.03 & 0.04 \\
\hline & Madagascar & 0.49 & -0.05 & 0.03 & 3.09 & 0.02 \\
\hline \multicolumn{7}{|c|}{ b. Within-community coefficient of variation of responses } \\
\hline Metric & Country & Moran's I index & Expected & Variance & $z$ Score & $P$ value \\
\hline \multirow{4}{*}{ Minimum fish size } & Kenya & -0.22 & -0.04 & 0.03 & -1.09 & 0.27 \\
\hline & Tanzania & 1.15 & -0.04 & 0.08 & 4.11 & 0.0001 \\
\hline & Mozambique & 0.19 & -0.07 & 0.07 & 1.01 & 0.31 \\
\hline & Madagascar & 0.10 & -0.05 & 0.03 & 0.86 & 0.39 \\
\hline \multirow[t]{4}{*}{ Gear restriction } & Kenya & 0.26 & -0.04 & 0.03 & 1.78 & 0.08 \\
\hline & Tanzania & 1.02 & -0.04 & 0.08 & 3.70 & 0.0002 \\
\hline & Mozambique & -0.25 & -0.07 & 0.07 & -0.71 & 0.48 \\
\hline & Madagascar & 0.35 & -0.05 & 0.03 & 2.34 & 0.02 \\
\hline \multirow[t]{4}{*}{ Species selection } & Kenya & 0.28 & -0.04 & 0.03 & 1.92 & 0.05 \\
\hline & Tanzania & 0.74 & -0.04 & 0.09 & 2.66 & 0.008 \\
\hline & Mozambique & 0.15 & -0.07 & 0.07 & 0.87 & 0.38 \\
\hline & Madagascar & 0.10 & -0.05 & 0.03 & 0.88 & 0.38 \\
\hline \multirow[t]{4}{*}{ Closed seasons } & Kenya & 0.29 & -0.04 & 0.03 & 1.99 & 0.05 \\
\hline & Tanzania & 0.57 & -0.04 & 0.08 & 2.18 & 0.03 \\
\hline & Mozambique & 0.06 & -0.07 & 0.07 & 0.51 & 0.61 \\
\hline & Madagascar & 0.57 & -0.05 & 0.03 & 3.49 & 0.0005 \\
\hline \multirow[t]{4}{*}{ Protected areas } & Kenya & 0.48 & -0.04 & 0.03 & 3.03 & 0.002 \\
\hline & Tanzania & 0.39 & -0.04 & 0.08 & 1.51 & 0.13 \\
\hline & Mozambique & 0.12 & -0.07 & 0.07 & 0.71 & 0.47 \\
\hline & Madagascar & -0.10 & -0.05 & 0.03 & -0.32 & 0.74 \\
\hline \multirow[t]{4}{*}{ Closed areas } & Kenya & 0.59 & -0.03 & 0.03 & 3.68 & 0.0002 \\
\hline & Tanzania & 0.03 & -0.04 & 0.08 & 0.29 & 0.77 \\
\hline & Mozambique & 0.47 & -0.07 & 0.07 & 1.95 & 0.05 \\
\hline & Madagascar & 0.24 & -0.05 & 0.03 & 1.59 & 0.11 \\
\hline
\end{tabular}




\begin{tabular}{|c|c|c|c|c|c|c|}
\hline \multirow[t]{4}{*}{ Pooled restrictions } & Kenya & 0.47 & -0.04 & 0.03 & 2.99 & 0.003 \\
\hline & Tanzania & 0.85 & -0.04 & 0.08 & 3.15 & 0.002 \\
\hline & Mozambique & 0.67 & -0.07 & 0.07 & 2.70 & 0.007 \\
\hline & Madagascar & 0.33 & -0.05 & 0.03 & 2.13 & 0.03 \\
\hline \multicolumn{7}{|c|}{ c. Between-community distances in responses } \\
\hline Metric & Country & Moran's I index & Expected & Variance & $z$ Score & $P$ value \\
\hline \multirow[t]{4}{*}{ Minimum fish size } & Kenya & 0.12 & -0.04 & 0.02 & 1.01 & 0.31 \\
\hline & Tanzania & 0.24 & -0.04 & 0.08 & 0.94 & 0.35 \\
\hline & Mozambique & 0.82 & -0.07 & 0.06 & 3.27 & 0.001 \\
\hline & Madagascar & 0.22 & -0.05 & 0.03 & 1.65 & 0.09 \\
\hline \multirow[t]{4}{*}{ Gear restriction } & Kenya & 0.18 & -0.04 & 0.03 & 1.35 & 0.18 \\
\hline & Tanzania & 0.91 & -0.04 & 0.08 & 3.30 & 0.0009 \\
\hline & Mozambique & 0.29 & -0.07 & 0.07 & 1.31 & 0.19 \\
\hline & Madagascar & 0.53 & -0.05 & 0.03 & 3.35 & 0.0008 \\
\hline \multirow[t]{4}{*}{ Species selection } & Kenya & 0.07 & -0.04 & 0.03 & 0.68 & 0.49 \\
\hline & Tanzania & 0.41 & -0.04 & 0.09 & 1.52 & 0.13 \\
\hline & Mozambique & 1.23 & -0.07 & 0.07 & 4.89 & 0.0001 \\
\hline & Madagascar & 0.40 & -0.05 & 0.03 & 2.53 & 0.01 \\
\hline \multirow[t]{4}{*}{ Closed seasons } & Kenya & 0.16 & -0.04 & 0.03 & 1.20 & 0.23 \\
\hline & Tanzania & 0.41 & -0.04 & 0.09 & 1.54 & 0.12 \\
\hline & Mozambique & 0.26 & -0.07 & 0.07 & 1.20 & 0.23 \\
\hline & Madagascar & 0.48 & -0.05 & 0.03 & 3.00 & 0.003 \\
\hline \multirow[t]{4}{*}{ Protected areas } & Kenya & 0.02 & -0.04 & 0.03 & 0.33 & 0.74 \\
\hline & Tanzania & 0.50 & -0.04 & 0.08 & 1.86 & 0.06 \\
\hline & Mozambique & 0.02 & -0.07 & 0.07 & 0.33 & 0.74 \\
\hline & Madagascar & 0.31 & -0.05 & 0.03 & 2.59 & 0.009 \\
\hline \multirow[t]{4}{*}{ Closed areas } & Kenya & 0.23 & -0.03 & 0.03 & 1.56 & 0.12 \\
\hline & Tanzania & 0.50 & -0.04 & 0.08 & 1.87 & 0.06 \\
\hline & Mozambique & 0.87 & -0.07 & 0.07 & 3.48 & 0.0005 \\
\hline & Madagascar & 0.25 & -0.05 & 0.03 & 1.69 & 0.09 \\
\hline \multirow[t]{4}{*}{ Pooled restrictions } & Kenya & 0.03 & -0.04 & 0.03 & 0.41 & 0.68 \\
\hline & Tanzania & 0.31 & -0.04 & 0.08 & 1.20 & 0.23 \\
\hline & Mozambique & 0.77 & -0.07 & 0.07 & 3.05 & 0.002 \\
\hline & Madagascar & 0.07 & -0.05 & 0.03 & 0.83 & 0.41 \\
\hline
\end{tabular}

preferences within communities must play some role in this variability because between- was higher than within-community variation.

Variation in the perceived benefits declined strongly as perceived benefits increased for within- but less so for between-community comparisons. This indicates that variations in costs/benefits described in Table 1 are not universal between neighbors. Tanzania was the one exception where between-community variation declined as perceived benefits increased, but the relationship was weak. Tanzania also fit our proposed cost/benefit scale best by having the greatest spread in restriction responses. Consequently, cost/benefit responses were spatially limited and could fail to be confirmed because of the competitive or polarizing effects of communications and interactions between neighboring communities. More communication is expected to reduce conflicts but can also produce polarization if neighbors are seen as potential defectors or competitors or as receiving unequal benefits from restrictions (Sugiarto et al. 2017). All mechanisms could work simultaneously and produce complex and patchy neighborhood relationships. Future research would benefit from studying the amount, type, and consequences of betweencommunity communication for achieving resource management goals in different national contexts.

Our findings support general patterns proposed by our hypotheses but also indicate contextual complexity and the importance of the nation, restrictions, and community interactions in predicting perceptions. Modeled behaviors suggest that local management benefits can be reduced when adherence levels between neighbors are not complementary (Agrawal et al. 2013). Consequently, high between-community variability in the perceived benefits for some restrictions could challenge successful compliance outcomes for many restrictions. One would predict better cooperative outcomes when communities are small or isolated from noncompliant neighbors, or when members adhere to and clearly benefit from enforcement (Powers and Lehmann 2013). Community size and market integration have therefore been good at predicting the status of fisheries and CPRM in the absence of effective enforcement or livelihood alternatives (Cinner 2005, McClanahan et al. 2006, Cinner et al. 2016). Diagnosing and developing successful policies and guidelines for CPRM will need to consider these contextual issues.

Key persons or regional or national entities may be required to communicate and ensure high compliance outside of small, isolated, and homogenous communities, particularly for restrictions with greater national than individual and community benefits. If stakeholders are susceptible to corruption and favor the interests of small over large groups, then the potential to increase productivity and achieve large-scale benefits will be challenged (Hardin 1968, Sundström 2015). Not preferentially benefiting smaller groups that typically design and enforce management is considered a fairer system for designing rules 
(Rawls 2001). Given that management designs and enforcement were done by national governments in Kenya and Tanzania, experienced fishers expressed cynicism about restrictions with large-scale benefits. This was especially common in Tanzania where conflicts with government have been commonly reported (Walley 2004, Benjaminsen and Bryceson 2012). Although many comanagement actions focus on strengthening local community governance, developing regional governance and intercommunity forums may be more important in nations with moderate capacity (Wright et al. 2016a).

Fairness in the perceptions of benefits was the strongest predictor of benefits and variation, especially in the wealthier countries and within, but also between, communities. Consequently, ensuring procedures of fairness and the distribution of benefits are options likely to increase compliance. Fairness can be achieved by attending to the four elements of justice: procedural, distributional, retributive, and restorative. Incorporating justice mechanisms into natural resource management should reduce the chances of marginalizing people historically excluded from justice (Schroeder et al. 2003, Giakoumi et al. 2018). For example, Kenyan stakeholders' perceptions of fisheries closures were shown to change from negative to neutral through transparent sharing of group benefit information (Cinner and McClanahan 2015). Reducing the costs of transactions is a key ingredient in many successful management and economic activities that should arise with increasing justice elements and the consequent trust that arises from fair and reliable transactions (Fukuyama 1995, Stern 2008).

Promoting jobs, permanence, and community organizations associated with positive views and lower variation in perceived benefits are among frequently proposed actions to improve perceptions and compliance in community and conservation development (Wright et al. 2016b). Nevertheless, our findings, like others, suggest they are weakly associated with proenvironmental behavior, perceived benefits of restrictions, low community variation, and considerably weaker than perceived benefits and fairness (Cinner 2009, 2014, McClanahan and Abunge 2016). Consequently, these options are likely be contextually important, but efforts to achieve procedural and distributional justice should be a priority for CPRM. Wealth and education did not predict positive perceptions toward restrictions and, therefore, are not likely to increase perceptions of benefits in our context. Consequently, a person's profession and sense of justice may be more important than wealth in predicting perceptions (Hicks et al. 2013, McClanahan and Abunge 2016, Turner et al. 2016). These two and other variables evaluated can often correlate and be potentially confounding when attributing causes of perceptions (Fig. 4). Multiple and hidden variables are a common problem when pooling people's values and behavioral responses into large or societal-level demographic analyses (Inglehart and Welzel 2005, Klöckner 2013). Consequently, the national socioeconomic context hypotheses we tested would require larger country sampling to better understand their roles in influencing perceptions of restrictions.

\section{Practical applications}

Our results have a number of practical applications for CPRM. One overarching application is to promote management that recognizes local to national scales of variability and to craft government policies and management accordingly. Second, the polling of stakeholders can help prioritize and identify social and geographic contexts for promoting specific types of management, closed and protected areas being examples of desired but controversial management options (McClanahan 2011, Caveen et al. 2014). Third, appropriately scaled democratic polling can also reduce the disproportionate influences of self-interested stakeholders and managers. Regardless of these potential uses, perceptions and rules of participation are important but do not directly translate into compliance and successful management (Ostrom 2006). Even where closures are controversial, such as Kenya, they have proliferated among communities that support them (Rocliffe et al. 2014). Their success in improving resources is, however, challenged by individuals within and between communities that do not comply with community decisions (McClanahan et al. 2016). Further, despite the broad recognition and agreement on gear restrictions, illegal gear types were commonly used in Kenya (McClanahan et al. 2005). Nevertheless, when intercommunity forums were held and followed by coenforcement of the agreed on gear types, illegal gear was reduced and yields increased (McClanahan 2007, 2010). Additionally, perceptions of a community closure changed as stakeholders experienced the lack of anticipated negative consequence once closures were in place (Cinner and McClanahan 2015).

Dependent on local social-ecological conditions and occupational options, perceptions are expected to align or polarize in adjacent communities (McClanahan et al. 2008, 2012). Consequently, polling of perceptions as we have done should help to identify, plan, and monitor the conflicts most expected to emerge in particular settings and over time. In Madagascar, for example, the preferred regulations were seasonal closure where we found high scaling of benefits and low variation. As would be predicted, there was a recent rapid proliferation of seasonal octopus (Octopus cyanea) closures in Madagascar (Rocliffe et al. 2014). Although generally successful, there was evidence for intercommunity breaching of closures that could reduce and negate benefits (Oliver et al. 2015). Consequently, low variation and clustering of community preferences has not fully eliminated breaches. Thus, imperfect compliance outcomes further emphasize the need for effective intercommunity and comanagement relationships, even for the least variable communities and restrictions. These examples beg the question of whether our results arise from recent experiences or from cultural predispositions to specific restrictions. In the case of Madagascar, many surveyed communities did not have seasonal closures, and therefore, positive views were unlikely to result from local experiences alone. Both predisposition and experiences are likely to play a role, and historical studies are required to better understand their influences on perceptions.

Conflicts over closures and other gear management systems in Kenya and Tanzania are likely to arise from negative experiences, disparate cost/benefit outcomes, and the availability of other occupational opportunities. To address conflicts, targeted communication is a starting point, especially for restrictions for costs/benefits that accrue on large time and spatial scales (Mbaru and Barnes 2017). Past perceptions of unfair practices and corrupt applications of policing could, however, be the source of this variability (Mulder et al. 2006). Regardless of the underlying 
causes of these perceptions, our results suggest that increasing the fairness of processes, reducing corruption, sharing benefits, and matching social and ecological scales for management are actions expected to lead to greater success. Given the effort to decentralize fisheries management in this region and globally (Cinner et al. 2012, Davis and Ruddle 2012), matching community costs and benefits with ecological variability is badly needed. The benefits of coordinated government bodies are not likely to be achieved by wholesale movements from national to federal governance, but rather by creating a compound republic of governance (Wagner 2005).

Can our polling approach lead to better management? It should increase the chances for clearly understanding management preferences and inclusive decision making, as well increasing the four justice procedures (Schroeder et al. 2003). Perceptions of equitable processes are at the core of many political conflicts, and polling and using perceptions to craft management should increase perceptions of fairness (Starmans et al. 2017). Nevertheless, polling is only one among other procedural justice options that can be considered. Additionally, agreement and enforcement become more challenging when they involve neighboring communities less involved in, or committed to, local procedures. Even if fishing communities are connected through coordination of government leaders and hierarchies, they are not always meaningfully engaged in critical channels of communications, which can lead to failure in adopting important decisions (Barnes et al. 2016). Additionally, a neighbor's resource is an easy target without consequences if sanctions are only applied to local stakeholders. If there is a lack of agreement or if restrictions are only locally enforceable, then betweenneighboring-community dilemmas and minimum-restriction matching may ensue (Agrawal et al. 2013).

Local decisions will often fail to protect the full spectrum of nature's diversity if local rather than larger scale restrictions are always the basis for decisions (Weeks et al. 2010). Many species and ecosystem processes require space and resources over scales larger than most fishing communities (Green et al. 2015, Isbell et al. 2017). In the WIO, we found neighboring communities were often $<10 \mathrm{~km}$ apart, and large-bodied and migratory species are unlikely to benefit from local management decisions unless they are shared broadly. There are some broadly shared restrictions, such as minimum size and gear restrictions, that can prevent the demise of fisheries resources (McClanahan et al. 2015). In the absence of shared decisions, procedures, and enforcement, the local polling and implementation of favored restrictions approach could favor only the profitability of economically important species with rapid growth and limited movements. Our study exposes contextual issues around demographic variability and the problems that local and overlapping governance institutions will need to address to better manage social-ecological dynamics. If demographic heterogeneity, economic developments, communication, state policies, and histories of justice and trust are not fully considered and crafted into management systems, the sustainably of CPRM will be challenged.

Responses to this article can be read online at: http://www.ecologyandsociety.org/issues/responses. php/10544

\section{Acknowledgments:}

The MASMA (Marine Science for Management) program of the WIOMSA (Western Indian Ocean Marine Science Association), the John D. and Catherine T. MacArthur Foundation, and USAID through the Global Fish Alliance (G-FISH) supported this research. We are grateful for the field assistance of $N$. Andrianarivelo, R. Charo, I. Ferreira, L. S. Jaribu, L. Josephat, P. Mahatante, N. Manjate, A. Rabearisoa, F. Ramahatratra, M. J. Rodrigues, and A. Wamukoto. Assistance with permissions and logistic support provided by Faculty of Aquatic Sciences, University of Dar es Salaam, Eduardo Mondline University, Kenya's Office of Science and Technology, Iniciativa Local para o Desenvolvimento Sustentável da Pesca de Baíana Pemba, FHI 360, G-FISH, World Wide Fund for Nature ( $W W F)$ and Wildlife Conservation Society (WCS) country offices, J. Barker, Z. Fonner, C. Holmes, L. Gaylord, A. Guissamulo, A. Jeque, A. T. Kamukuru, Z. Machona, G.D. Msumi, J. Ndagala, E. Neteque, and H. Randriahmahazo is greatly appreciated. M. Azali assisted with the production of tables and graphs.

\section{LITERATURE CITED}

Agrawal, A. 2003. Sustainable governance of common-pool resources: context, methods and politics. Annual Review of Anthropology 32:243-262. http://dx.doi.org/10.1146/annurev. anthro.32.061002.093112

Agrawal, A., D. G. Brown, G. Rao, R. Riolo, D. T. Robinson, and M. Bommarito II. 2013. Interactions between organizations and networks in common-pool resource governance. Environmental Science \& Policy 25:138-146. http://dx.doi.org/10.1016/j. envsci.2012.08.004

Araral, E. 2014. Ostrom, Hardin and the commons: a critical appreciation and a revisionist view. Environmental Science \& Policy 36:11-23. http://dx.doi.org/10.1016/j.envsci.2013.07.011

Barnes, M. L., J. Lynham, K. Kalberg, and P. Leung. 2016. Social networks and environmental outcomes. Proceedings of the National Academy of Sciences of the United States of America 113:6466-6471. http://dx.doi.org/10.1073/pnas.1523245113

Benjaminsen, T. A., and I. Bryceson. 2012. Conservation, green/ blue grabbing and accumulation by dispossession in Tanzania. Journal of Peasant Studies 39:335-355. http://dx.doi. org/10.1080/03066150.2012.667405

Bennett, N. J. 2016. Using perceptions as evidence to improve conservation and environmental management. Conservation Biology 30:582-592. http://dx.doi.org/10.1111/cobi.12681

Burke, L., K. Reytar, M. Spalding, and A. Perry. 2011. Reefs at risk revisited. World Resources Institute, Washington, D.C., USA.

Carrascosa, J. M., R. Cuevas, R. Gonzalez, A. Azcorra, and D. Garcia. 2015. Quantifying the economic and cultural biases of social media through trending topics. PLOS ONE 10:e134407. http://dx.doi.org/10.1371/journal.pone.0134407

Carret, J. C. 2013. Madagascar country environmental analysis (CEA): taking stock and moving forward. World Bank, Washington, D.C., USA. 
Caveen, A., N. Polunin, T. Gray, and S. M. Stead. 2014. The controversy over marine protected areas: science meets policy. Springer International, Cham, Switzerland.

Cinner, J. 2005. Socioeconomic factors influencing customary marine tenure in the Indo-Pacific. Ecology and Society 10(1):36. http://dx.doi.org/10.5751/ES-01364-100136

Cinner, J. E. 2009. Poverty and the use of destructive fishing gear near east African marine protected areas. Environmental Conservation 36:321-326. http://dx.doi.org/10.1017/S0376892910000123

Cinner, J. 2014. Coral reef livelihoods. Current Opinion in Environmental Sustainability 7:65-71. http://dx.doi.org/10.1016/j. cosust.2013.11.025

Cinner, J. E., T. M. Daw, T. R. McClanahan, N. Muthiga, C. Abunge, S. Hamed, B. Mwaka, A. Rabearisoa, A. Wamukota, E. Fisher, and N. Jiddawi. 2012. Transitions toward co-management: the process of marine resource management devolution in three east African countries. Global Environmental Change 22:651-658. http://dx.doi.org/10.1016/j.gloenvcha.2012.03.002

Cinner, J., M. M. P. B. Fuentes, and H. Randriamahazo. 2009. Exploring social resilience in Madagascar's marine protected areas. Ecology and Society 14(1):41. http://dx.doi.org/10.5751/ ES-02881-140141

Cinner, J. E., C. Huchery, M. A. MacNeil, N. A. J. Graham, T. R. McClanahan, J. Maina, E. Maire, J. N. Kittinger, C. C. Hicks, C. Mora, E. H. Allison, S. D'Agata, A. Hoey, D. A. Feary, L. Crowder, I. D. Williams, M. Kulbicki, L. Vigliola, L. Wantiez, G. Edgar, R. D. Stuart-Smith, S. A. Sandin, A. L. Green, M. J. Hardt, M. Beger, A. Friedlander, S. J. Campbell, K. E. Holmes, S. K. Wilson, E. Brokovich, A. J. Brooks, J. J. Cruz-Motta, D. J. Booth, P. Chabanet, C. Gough, M. Tupper, S. C. A. Ferse, U. R. Sumaila, and D. Mouillot. 2016. Bright spots among the world's coral reefs. Nature 535:416-419. http://dx.doi.org/10.1038/nature18607

Cinner, J. E., and T. R. McClanahan. 2015. A sea change on the African coast? Preliminary social and ecological outcomes of a governance transformation in Kenyan fisheries. Global Environmental Change 30:133-139. http://dx.doi.org/10.1016/j. gloenvcha.2014.10.003

Cinner, J. E., and R. B. Pollnac. 2004. Poverty, perceptions and planning: why socioeconomics matter in the management of Mexican reefs. Ocean \& Coastal Management 47:479-493. http:// dx.doi.org/10.1016/j.ocecoaman.2004.09.002

Cox, M., G. Arnold, and S. V. Tomas. 2010. A review of design principles for community-based natural resource management. Ecology and Society 15(4):38. http://dx.doi.org/10.5751/ ES-03704-150438

Cudney-Bueno, R., and X. Basurto. 2009. Lack of cross-scale linkages reduces robustness of community-based fisheries management. PLoS ONE 4:e6253. http://dx.doi.org/10.1371/ journal.pone. 0006253

Cumming, G. S., D. H. M. Cumming, and C. L. Redman. 2006. Scale mismatches in social-ecological systems: causes, consequences, and solutions. Ecology and Society 11(1):14. http:// dx.doi.org/10.5751/ES-01569-110114
Davis, A., and K. Ruddle. 2012. Massaging the misery: recent approaches to fisheries governance and the betrayal of small-scale fisheries. Human Organization 71:244-254. http://dx.doi. org/10.17730/humo.71.3.205788362x751128

Daw, T., K. Brown, S. Rosendo, and R. Pomeroy. 2011. Applying the ecosystem services concept to poverty alleviation: the need to disaggregate human well-being. Environmental Conservation 38: 370-379. http://dx.doi.org/10.1017/S0376892911000506

Daw, T. M., S. Coulthard, W. W. L. Cheung, K. Brown, C. Abunge, D. Galafassi, G. D. Peterson, T. R. McClanahan, J. O. Omukoto, and L. Munyi. 2015. Evaluating taboo trade-offs in ecosystems services and human well-being. Proceedings of the National Academy of Sciences of the United States of America 112:6949-6954. http://dx.doi.org/10.1073/pnas.1414900112

Daw, T. M., C. Hicks, K. Brown, T. Chaigneau, F. JanuchowskiHartley, W. Cheung, S. Rosendo, B. Crona, S. Coulthard, C. Sandbrook, C. Perry, S. Bandeira, N. A. Muthiga, B. SchulteHerbrüggen, J. Bosire, and T. R. McClanahan, 2016. Elasticity in ecosystem services: exploring the variable relationship between ecosystems and human well-being. Ecology and Society 21(2):11. http://dx.doi.org/10.5751/ES-08173-210211

Fukuyama, F. 1995. Trust: the social virtues and the creation of prosperity. Free, New York, New York, USA.

Fukuyama, F. 2011. The origins of political order: from prehuman times to the French Revolution. Profile Books, London, UK.

Giakoumi, S., J. McGowan, M. Mills, M. Beger, R. H. Bustamante, A. Charles, P. Christie, M. Fox, P. GarciaBorboroglu, S. Gelcich, P. Guidetti, P. Mackelworth, J. M. Maina, L. McCook, F. Micheli, L. E. Morgan, P. J. Mumby, L. M. Reyes, A. White, K. Grorud-Colvert, and H. P. Possingham. 2018. Revisiting "success" and "failure" of marine protected areas: a conservation scientist perspective. Frontiers in Marine Science 5:223. http://dx.doi.org/10.3389/fmars.2018.00223

Gill, D. A., M. B. Mascia, G. N. Ahmadia, L. Glew, S. E. Lester, M. Barnes, I. Craigie, E. S. Darling, C. M. Free, J. Geldmann, S. Holst, O. P. Jensen, A. T. White, X. Basurto, L. Coad, R. D. Gates, G. Guannel, P. J. Mumby, H. Thomas, S. Whitmee, S. Woodley, and H. E. Fox. 2017. Capacity shortfalls hinder the performance of marine protected areas globally. Nature 543:665-669. http://dx. doi.org/10.1038/nature21708

Green, A. L., A. P. Maypa, G. R. Almany, K. L. Rhodes, R. Weeks, R. A. Abesamis, M. G. Gleason, P. J. Mumby, and A. T. White. 2015. Larval dispersal and movement patterns of coral reef fishes, and implications for marine reserve network design. Biological Reviews 90:1215-1247. http://dx.doi.org/10.1111/brv.12155

Gutiérrez, N. L., R. Hilborn, and O. Defeo. 2011. Leadership, social capital and incentives promote successful fisheries. Nature 470:386-389. http://dx.doi.org/10.1038/nature09689

Hardin, G. 1968. The tragedy of the commons. Science 162:1243-1248. http://dx.doi.org/10.1126/science.162.3859.1243

Hicks, C. C. 2011. How do we value our reefs? Risks and tradeoffs across scales in "biomass-based" economies. Coastal Management 39:358-376. http://dx.doi.org/10.1080/08920753.2011.589219 
Hicks, C. C., J. E. Cinner, N. Stoeckl, and T. R. McClanahan. 2015. Linking ecosystem services and human-values theory. Conservation Biology 29:1471-1480. http://dx.doi.org/10.1111/ cobi. 12550

Hicks, C. C., N. A. J. Graham, and J. E. Cinner. 2013. Synergies and tradeoffs in how managers, scientists, and fishers value coral reef ecosystem services. Global Environmental Change 23:1444-1453. http://dx.doi.org/10.1016/j.gloenvcha.2013.07.028

Hofstede, G., G. J. Hofstede, and M. Minkov. 2010. Cultures and organizations: software of the mind. McGraw-Hill Professional, New York, New York, USA.

Horrill C, A. T. Kamukuru, Y. D Mgaya, and M. Risk. 2000. Northern Tanzania, Zanzibar and Pemba. Pages 167-198 in T. R. McClanahan, C. R. C. Sheppard, and D. O. Obura, editors. Coral reefs of the Indian Ocean: their ecology and conservation. Oxford University Press, New York, New York, USA.

Inglehart, R., and C. Welzel. 2005. Modernization, cultural change, and democracy: the human development sequence. Cambridge University Press, Cambridge, UK. http://dx.doi.org/10.1017/ CBO9780511790881

Isbell, F., A. Gonzalez, M. Loreau, J. Cowles, S. Díaz, A. Hector, G. M. Mace, D. A. Wardle, M. I. O’Connor, J. E. Duffy, L. A. Turnbull, P. L. Thompson, and A. Larigauderie. 2017. Linking the influence and dependence of people on biodiversity across scales. Nature 546:65-72. http://dx.doi.org/10.1038/nature22899

Josse, J., and F. Husson. 2016. missMDA: a package for handling missing values in multivariate data analysis. Journal of Statistical Software 70:1-31. http://dx.doi.org/10.18637/jss.v070.i01

Kamat, V. 2014. "The ocean is our farm": marine conservation, food insecurity, and social suffering in southeastern Tanzania. Human Organization 73:289-298. http://dx.doi.org/10.17730/ $\underline{\text { humo.73.3.f43k115544761g0v }}$

Kassambara, A., and F. Mundt. 2016. Factoextra: extract and visualize the results of multivariate data analyses. $\mathrm{R}$ package version 1.3. R Foundation for Statistical Computing, Vienna, Austria. [online] URL: https://cran.r-project.org/package= factoextra

Katikiro, R. E., E. D. Macusi, and K. H. M. A. Deepananda. 2015. Challenges facing local communities in Tanzania in realising locally-managed marine areas. Marine Policy 51:220-229. http://dx.doi.org/10.1016/j.marpol.2014.08.004

Klöckner, C. A. 2013. A comprehensive model of the psychology of environmental behaviour - a meta-analysis. Global Environmental Change 23:1028-1038. http://dx.doi.org/10.1016/j.gloenvcha.2013.05.014

Koontz, T. M., D. Gupta, P. Mudliar, and P. Ranjan. 2015. Adaptive institutions in social-ecological systems governance: a synthesis framework. Environmental Science \& Policy 53B:139-151. http://dx.doi.org/10.1016/j.envsci.2015.01.003

Levin, N., M. Beger, J. Maina, T. McClanahan, and S. Kark. 2018. Evaluating the potential for transboundary management of marine biodiversity in the Western Indian Ocean. Australasian Journal of Environmental Management 25:62-85. http://dx.doi. org/10.1080/14486563.2017.1417167
Mbaru, E. K., and M. L. Barnes. 2017. Key players in conservation diffusion: using social network analysis to identify critical injection points. Biological Conservation 210A:222-232. http://dx.doi.org/10.1016/j.biocon.2017.03.031

McClanahan, T. R. 2007. Management of area and gear in Kenyan coral reefs. Pages 166-185 in T. R. McClanahan and J. C. Castilla, editors. Fisheries management: progress towards sustainability. Blackwell, London, UK. http://dx.doi. org/10.1002/9780470996072.ch8

McClanahan, T. R. 2010. Effects of fisheries closures and gear restrictions on fishing income in a Kenyan coral reef. Conservation Biology 24:1519-1528. http://dx.doi.org/10.1111/j.1523-1739.2010.01530. $\underline{\mathrm{X}}$

McClanahan, T. R. 2011. Human and coral reef use interactions: from impacts to solutions? Journal of Experimental Marine Biology and Ecology 408:3-10. http://dx.doi.org/10.1016/j. jembe.2011.07.021

McClanahan, T. R., and C. A. Abunge. 2016. Perceptions of fishing access restrictions and the disparity of benefits among stakeholder communities and nations of south-eastern Africa. Fish and Fisheries 17:417-437. http://dx.doi.org/10.1111/ faf.12118

McClanahan, T. R., and C. A. Abunge. 2017. Fish trader's gender and niches in a declining coral reef fishery: implications for sustainability. Ecosystem Health and Sustainability 3:1353288. http://dx.doi.org/10.1080/20964129.2017.1353288

McClanahan, T. R., C. A. Abunge, and J. E. Cinner. 2012. Heterogeneity in fishers' and managers' preferences towards management restrictions and benefits in Kenya. Environmental Conservation 39:357-369. http://dx.doi.org/10.1017/S0376892912000197

McClanahan, T. R., J. C. Castilla, A. T. White, and O. Defeo, $2009 a$. Healing small-scale fisheries by facilitating complex socioecological systems. Reviews in Fish Biology and Fisheries 19:33-47. http://dx.doi.org/10.1007/s11160-008-9088-8

McClanahan, T. R., J. E. Cinner, C. Abunge, A. Rabearisoa, P. Mahatante, F. Ramahatratra, and N. Andrianarivelo. 2014. Perceived benefits of fisheries management restrictions in Madagascar. Ecology and Society 19(1):5. http://dx.doi. org/10.5751/ES-06080-190105

McClanahan, T. R., J. Cinner, A. T. Kamukuru, C. Abunge, and J. Ndagala. 2008. Management preferences, perceived benefits and conflicts among resource users and managers in the Mafia Island Marine Park, Tanzania. Environmental Conservation 35:340-350. http://dx.doi.org/10.1017/S0376892908005250

McClanahan, T., J. Davies, and J. Maina. 2005. Factors influencing resource users and managers' perceptions towards marine protected area management in Kenya. Environmental Conservation 32:42-49. http://dx.doi.org/10.1017/S0376892904001791

McClanahan, T. R., H. Glaesel, J. Rubens, and R. Kiambo. 1997. The effects of traditional fisheries management on fisheries yields and the coral-reef ecosystems of southern Kenya. Environmental Conservation 24:105-120. http://dx.doi.org/10.1017/S0376892997000179

McClanahan, T. R., N. A. J. Graham, M. A. MacNeil, and J. E. Cinner. 2015. Biomass-based targets and the management of 
multispecies coral reef fisheries. Conservation Biology 29:409-417. http://dx.doi.org/10.1111/cobi.12430

McClanahan, T. R., and C. Jadot. 2017. Managing coral reef fish community biomass is a priority for biodiversity conservation in Madagascar. Marine Ecology Progress Series 580:169-190. http:// dx.doi.org/10.3354/meps 12267

McClanahan, T. R., M. J. Marnane, J. E. Cinner, and W. E. Kiene. 2006. A comparison of marine protected areas and alternative approaches to coral-reef management. Current Biology 16:1408-4113. http://dx.doi.org/10.1016/j.cub.2006.05.062

McClanahan, T. R, and N. A. Muthiga. 2017. Environmental variability indicates a climate-adaptive center under threat in northern Mozambique coral reefs. Ecosphere 8:e1812. http://dx. doi.org/10.1002/ecs2.1812

McClanahan, T., N. A. Muthiga, and C. A. Abunge. 2016. Establishment of community managed fisheries' closures in Kenya: early evolution of the tengefu movement. Coastal Management 44:1-20. http://dx.doi.org/10.1080/08920753.2016.1116667

McClanahan, T. R., N. A. Muthiga, J. Maina, A. T. Kamukuru, and S. A. S. Yahya. 2009b. Changes in northern Tanzania coral reefs during a period of increased fisheries management and climatic disturbance. Aquatic Conservation: Marine and Freshwater Ecosystems 19:758-771. http://dx.doi.org/10.1002/ aqc. 1020

McClanahan, T. R., and P. S. Rankin. 2016. Geography of conservation spending, biodiversity, and culture. Conservation Biology 30:1089-1101. http://dx.doi.org/10.1111/cobi.12720

McPherson, M., L. Smith-Lovin, and J. M. Cook. 2001. Birds of a feather: homophily in social networks. Annual Review of Sociology 27:415-444. http://dx.doi.org/10.1146/annurev.soc.27.1.415

Mulder, L. B., E. van Dijk, D. De Cremer, and H. A. M. Wilke. 2006. Undermining trust and cooperation: the paradox of sanctioning systems in social dilemmas. Journal of Experimental Social Psychology 42:147-162. http://dx.doi.org/10.1016/j. jesp.2005.03.002

Odum, W. E. 1982. Environmental degradation and the tyranny of small decisions. BioScience 32:728-729. http://dx.doi. org/10.2307/1308718

Oliver, T. A., K. L. L. Oleson, H. Ratsimbazafy, D. Raberinary, S. Benbow, and A. Harris. 2015. Positive catch \& economic benefits of periodic octopus fishery closures: do effective, narrowly targeted actions 'catalyze' broader management? PLoS ONE 10:e0129075. http://dx.doi.org/10.1371/journal.pone.0129075

Ostrom, E. 2006. The complexity of rules and how they may evolve over time. Pages 114-136 in C. Schubert and G. von Wangenheim, editors. Evolution and design of institutions. Routledge, London, UK.

Ostrom, E. 2010. Analyzing collective action. Agricultural Economics 41:155-166. http://dx.doi.org/10.1111/j.1574-0862.2010.00497. $\underline{\mathrm{x}}$

Pauly, D. 2007. The Sea Around Us Project: documenting and communicating global fisheries impacts on marine ecosystems. AMBIO: A Journal of the Human Environment 36:290-295. https://doi.org/10.1579/0044-7447(2007)36[290:TSAUPD]2.0.CO;2
Powers, S. T., and L. Lehmann. 2013. The co-evolution of social institutions, demography, and large-scale human cooperation. Ecology Letters 16:1356-1364. http://dx.doi.org/10.1111/ele.12178

Rawls, J. 2001. Justice as fairness: a restatement. Harvard University Press, Cambridge, Massachusetts, USA.

R Development Core Team. 2015. R: a language and environment for statistical computing. R Foundation for Statistical Computing, Vienna, Austria.

Rocliffe, S., S. Peabody, M. Samoilys, and J. P. Hawkins. 2014. Towards a network of locally managed marine areas (LMMAs) in the Western Indian Ocean. PLoS ONE 9:e103000. http://dx. doi.org/10.1371/journal.pone. 0103000

Sall, J., A. Lehmaan, and L. Creighton. 2001. JMP start statistics: a guide to statistics and data analysis. Second edition. Duxbury, Belmont, California, USA.

Saunders, F. P. 2014. The promise of common pool resource theory and the reality of commons projects. International Journal of the Commons 8:636-656. http://dx.doi.org/10.18352/ijc.477

Schroeder, D. A., J. E. Steel, A. J. Woodell, and A. F. Bembenek. 2003. Justice within social dilemmas. Personality and Social Psychology Review 7:374-387. http://dx.doi.org/10.1207/ S15327957PSPR0704 09

Starmans, C., M. Sheskin, and P. Bloom. 2017. Why people prefer unequal societies. Nature Human Behaviour 1:0082. http://dx.doi. org/10.1038/s41562-017-0082

Stern, M. J. 2008. The power of trust: toward a theory of local opposition to neighboring protected areas. Society \& Natural Resources 21:859-875. http://dx.doi.org/10.1080/08941920801973763

Sugiarto, H. S., J. S. Lansing, N. N. Chung, C. H. Lai, S. A. Cheong, and L. Y. Chew, 2017. Social cooperation and disharmony in communities mediated through common pool resource exploitation. Physical Review Letters 118:208301. http:// dx.doi.org/10.1103/PhysRevLett.118.208301

Sundström, A. 2015. Covenants with broken swords: corruption and law enforcement in governance of the commons. Global Environmental Change 31:253-262. http://dx.doi.org/10.1016/j. gloenvcha.2015.02.002

Teh, L. S. L., L. C. L. Teh, and U. R. Sumaila. 2013. A global estimate of the number of coral reef fishers. PLoS ONE 8:e65397. https://doi.org/10.1371/journal.pone.0065397

Turner, R. A., J. Addison, A. Arias, B. J. Bergseth, N. A. Marshall, T. H. Morrison, and R. C. Tobin. 2016. Trust, confidence, and equity affect the legitimacy of natural resource governance. Ecology and Society 21(3):18. http://dx.doi.org/10.5751/ ES-08542-210318

Wagner, R. E. 2005. Self-governance, polycentrism, and federalism: recurring themes in Vincent Ostrom's scholarly oeuvre. Journal of Economic Behavior \& Organization 52:173-188. http://dx.doi.org/10.1016/j.jebo.2004.06.015

Walley, C. J. 2004. Rough waters: nature and development in an East African marine park. Princeton University Press, Princeton, New Jersey, USA. http://dx.doi.org/10.1515/9781400835751 
Weeks, R., G. R. Russ, A. C. Alcala, and A. T. White. 2010. Effectiveness of marine protected areas in the Philippines for biodiversity conservation. Conservation Biology 24:531-540. http://dx.doi.org/10.1111/j.1523-1739.2009.01340.x

Wells, S., N. Burgess, and A. Ngusaru. 2007. Towards the 2012 marine protected area targets in Eastern Africa. Ocean \& Coastal Management 50:67-83. http://dx.doi.org/10.1016/j.

ocecoaman.2006.08.012

Wright, G. D., K. P. Andersson, C. C. Gibson, and T. P. Evans. 2016a. Decentralization can help reduce deforestation when user groups engage with local government. Proceedings of the National Academy of Sciences of the United States of America 113:14958-14963. http://dx.doi.org/10.1073/pnas.1610650114

Wright, J. H., N. A. O. Hill, D. Roe, J. M. Rowcliffe, N. F. Kümpel, M. Day, F. Booker, and E. J. Milner-Gulland. 2016b. Reframing the concept of alternative livelihoods. Conservation Biology 30:7-13. http://dx.doi.org/10.1111/cobi.12607 
Appendix 1. Fisheries Management Questionnaire

Date:

Landing site:

District:

1. What type of fishing method(s) do you use? After list is complete, ask respondent to rank in order of importance

\begin{tabular}{|l|l|}
\hline Trap & Spear gun \\
\hline Gillnet & Shark net \\
\hline Line & Other \\
\hline Beach seine & NA \\
\hline
\end{tabular}

Now I am going to ask you a series of questions about your opinion on the different ways that fisheries could be managed. First, I'd like to ask you some questions about prohibiting certain types of GEAR

2a. Do you think gear restrictions are a good way to maintain fish catch?

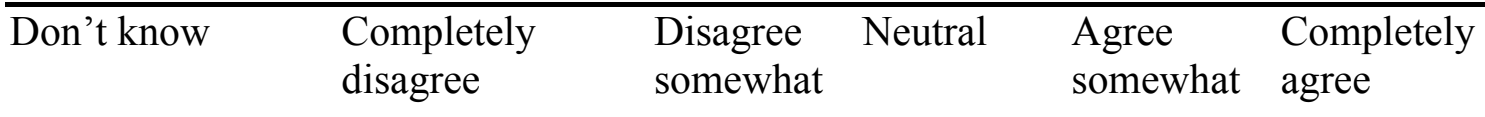

2b. How much would you like to XXX to be restricted

\begin{tabular}{|c|c|c|c|c|c|}
\hline Gear (XXX) & $\begin{array}{l}\text { Should not } \\
\text { be restricted }\end{array}$ & Slightly & Important & $\begin{array}{l}\text { Very } \\
\text { important }\end{array}$ & Don't know \\
\hline
\end{tabular}

Trap

Gillnet

Line

Beach Seine

Spear Gun

Shark Net

Other

2c.Do you think other fishers would support the idea of gear restriction?

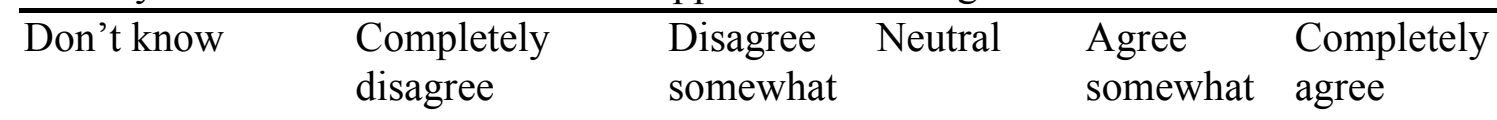

Why do you think so?

2d. To what degree do you think you would benefit from gear restrictions?

\begin{tabular}{|l|l|l|l|l|l|l|l|l|l|l|}
\hline & $\mathbf{1}$ & $\mathbf{2}$ & $\mathbf{3}$ & $\mathbf{4}$ & $\mathbf{5}$ & $\mathbf{6}$ & $\mathbf{7}$ & $\mathbf{8}$ & $\mathbf{9}$ & $\mathbf{1 0}$ \\
\hline Self & & & & & & & & & & \\
\hline Community & & & & & & & & & & \\
\hline
\end{tabular}




\section{Government}

Now, I would like to ask you some questions about CLOSED SEASONS

3a. Do you think that a closed season is a good way to maintain catches?

3b. How long should the closed season be? (from when to when?)

Why?

3c. Do you think other fishers will support the idea?

\begin{tabular}{|c|c|c|c|c|}
\hline Don't know & $\begin{array}{l}\text { Completely } \\
\text { disagree }\end{array}$ & $\begin{array}{l}\text { Disagree } \\
\text { somewhat }\end{array}$ & Neutral & $\begin{array}{l}\text { Agree } \\
\text { somewhat }\end{array}$ \\
\hline
\end{tabular}

Why

3d. To what degree do you think you would benefit from a closed season?

\begin{tabular}{|l|l|l|l|l|l|l|l|l|l|l|}
\hline & $\mathbf{1}$ & $\mathbf{2}$ & $\mathbf{3}$ & $\mathbf{4}$ & $\mathbf{5}$ & $\mathbf{6}$ & $\mathbf{7}$ & $\mathbf{8}$ & $\mathbf{9}$ & $\mathbf{1 0}$ \\
\hline Self & & & & & & & & & & \\
\hline Community & & & & & & & & & & \\
\hline Government & & & & & & & & & & \\
\hline
\end{tabular}

Now, I'd like to ask you about having a MINIMUM SIZE on the fish that are caught

4a. Do you think there should be a minimum size of fish ( local examples) fish caught as away to maintain fish around here?

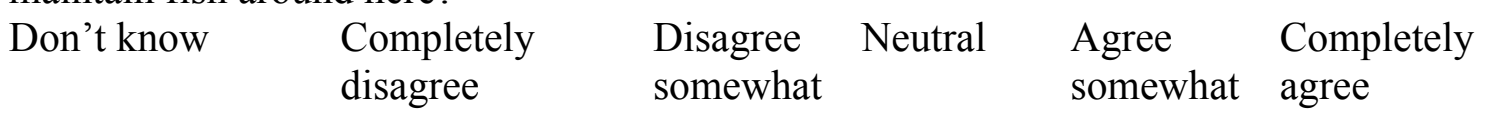

4b. What should be the minimum size that can maintain fish around here?

Species Size (cm- use ruler)

4c. Do you think that other fishers would agree to have a minimum size of fish?

\begin{tabular}{|c|c|c|c|c|}
\hline Don't know & $\begin{array}{l}\text { Completely } \\
\text { disagree }\end{array}$ & $\begin{array}{l}\text { Disagree } \\
\text { somewhat }\end{array}$ & Neutral & $\begin{array}{l}\text { Agree } \\
\text { somewhat }\end{array}$ \\
\hline
\end{tabular}

Why

4d. To what degree do you think you would benefit from not fishing small fish?

No benefit Small Medium Big benefit Don't know




\begin{tabular}{|c|c|c|c|c|c|c|c|c|c|c|}
\hline & & & & & & & & & & \\
\hline & 1 & 2 & 3 & 4 & 5 & 6 & 7 & 8 & 9 & 10 \\
\hline Self & & & & & & & & & & \\
\hline Community & & & & & & & & & & \\
\hline Government & & & & & & & & & & \\
\hline
\end{tabular}

Now I'm going to ask you some questions about SPECIES RESTRICTIONS

5a. Do you think that not keeping certain kinds of fish (local example) is a good way to maintain fish around here?

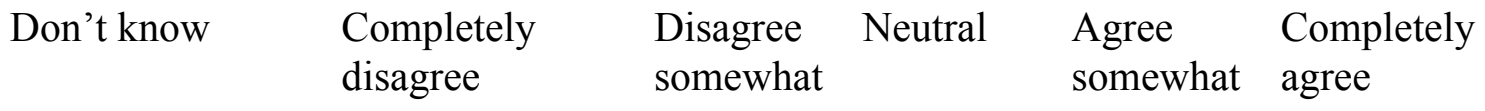

5b. Which species should be restricted

Why

5c. Do you think that other fishers would agree to not keeping certain kind of fish?

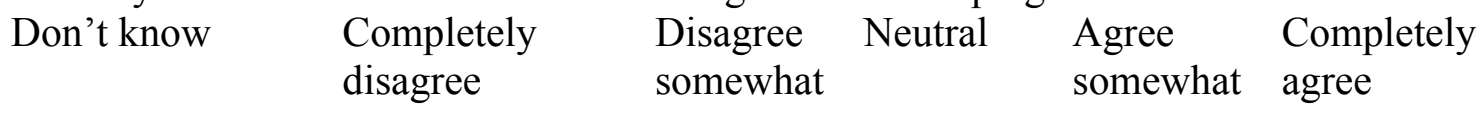

Why

$5 \mathrm{~d}$. To what degree do you think you would benefit from not keeping certain kind of fish?

\begin{tabular}{|l|l|l|l|l|l|l|l|l|l|l|}
\hline & $\mathbf{1}$ & $\mathbf{2}$ & $\mathbf{3}$ & $\mathbf{4}$ & $\mathbf{5}$ & $\mathbf{6}$ & $\mathbf{7}$ & $\mathbf{8}$ & $\mathbf{9}$ & $\mathbf{1 0}$ \\
\hline Self & & & & & & & & & & \\
\hline Community & & & & & & & & & & \\
\hline Government & & & & & & & & & & \\
\hline
\end{tabular}

\section{CLOSED AREAS}

6a. Do you believe that a closed area is a good way to maintain fish catch?

\begin{tabular}{|c|c|c|c|}
\hline Don't know & Completely & Disagree & Neutr \\
\hline
\end{tabular}

6b. If there were to be a closed area in Pemba Bay, where do you think it should be?

6c. How big should the closed area be? (meters, hectares, kilometer?)

6d. Do you think other fishers would agree to a closed area? 


\begin{tabular}{|c|c|c|c|c|c|}
\hline Don't know & $\begin{array}{l}\text { Completely } \\
\text { disagree }\end{array}$ & $\begin{array}{l}\text { Disagree } \\
\text { somewhat }\end{array}$ & Neutral & $\begin{array}{l}\text { Agree } \\
\text { somewhat }\end{array}$ & $\begin{array}{l}\text { Completely } \\
\text { agree }\end{array}$ \\
\hline
\end{tabular}

Why

6d. To what degree do you think you would benefit from a closed area? Scale the response from least on the left to most on the right.

\begin{tabular}{|l|l|l|l|l|l|l|l|l|l|l|}
\hline & $\mathbf{1}$ & $\mathbf{2}$ & $\mathbf{3}$ & $\mathbf{4}$ & $\mathbf{5}$ & $\mathbf{6}$ & $\mathbf{7}$ & $\mathbf{8}$ & $\mathbf{9}$ & $\mathbf{1 0}$ \\
\hline Self & & & & & & & & & & \\
\hline Community & & & & & & & & & & \\
\hline Government & & & & & & & & & & \\
\hline
\end{tabular}

\section{CONFLICTS}

8a.Do you have conflicts with other fishers? b. What types of conflict

9. What kinds of fishers are involved in conflicts?

\section{LIVELIHOODS}

Now I am going to ask you some questions about your livelihood

10 . How many people live in your house?

\begin{tabular}{|l|l|l|l|}
\hline Adult male & Adult female & Male children & Female children \\
\hline
\end{tabular}

11. What jobs do you and other people in your house do that bring in food or money to your house?

\begin{tabular}{|c|c|c|c|c|}
\hline ACTIVITY & $\begin{array}{l}\text { Check if } \\
\text { respondent }\end{array}$ & $\begin{array}{l}\text { \# of } \\
\text { People }\end{array}$ & $\begin{array}{l}\text { Rank of } \\
\text { Importance }\end{array}$ & Notes/Detail \\
\hline \multicolumn{4}{|l|}{ Fishing } & \\
\hline \multicolumn{4}{|l|}{ Gleaning } & \\
\hline \multicolumn{4}{|l|}{ Mari culture } & \\
\hline \multicolumn{4}{|l|}{ Marketing Marine Products } & \\
\hline \multicolumn{4}{|l|}{ Farming } & \\
\hline \multicolumn{4}{|l|}{ Cash Crops } & \\
\hline \multicolumn{4}{|l|}{ Salaried Employment } & \\
\hline \multicolumn{4}{|l|}{ Tourism } & \\
\hline \multicolumn{4}{|l|}{$\begin{array}{l}\text { Informal Economic } \\
\text { Activities }\end{array}$} & \\
\hline Other & & & & \\
\hline
\end{tabular}

12. What other work have you done in the last 5 years?

\begin{tabular}{|l|l|l|l|l|}
\hline Occupation & Main job & Why stop? & Could get similar & Prefer current or \\
\hline
\end{tabular}




\begin{tabular}{|l|l|l|l|l|}
\hline & & & now? (y/n) & previous job (c/p) \\
\hline & & & & \\
\hline & & & & \\
\hline
\end{tabular}

\section{Demographics}

13a. Where are you originally from?

\begin{tabular}{|l|l|l|l|}
\hline This community & This region & This country & Other country \\
\hline
\end{tabular}

13b. IF NOT FROM THIS COMMUNITY-How long have you lived in XXX?

13c. IF NOT FROM THIS COMMUNITY Why did you move to XXX?

\begin{tabular}{|l|l|l|l|}
\hline Fishing & Other work & Family \& friends & Health/spiritual \\
\hline Other & \multicolumn{3}{|l|}{} \\
\hline
\end{tabular}
14. Age
15.Sex
16. Religion
17. Ethnicity

18. Highest grade of education you have attained?

\section{Well-being}

19. Last fortnightly (two week) expenditures

20. I am interested in understanding what your home is like, so I am going to ask you some questions about the type of house you have and the things in your house.

20a. Appliances

\begin{tabular}{|l|l|l|l|l|}
\hline Generator & Electricity & Solar & Modern stove & Mobile phones \\
\hline TV & Electric fan & Satellite dish & Piped water & Mirror \\
\hline Refrigerator & $\begin{array}{l}\text { Radio/cassette } \\
\text { player }\end{array}$ & VCR & Water tank & Type of light \\
\hline Vehicle & Rope bed & Wall unit & & \\
\hline
\end{tabular}

20b. Furniture

\begin{tabular}{|l|l|l|l|l|l|}
\hline Chairs & None & Plastic & Bamboo/bush material & Wood & Sofa \\
\hline Table & None & Plastic & Bamboo/bush material & Wood & Glass \\
\hline
\end{tabular}

20c. Roof material

\begin{tabular}{|c|c|c|c|}
\hline Thatch & Metal & Tile & Other \\
\hline \multicolumn{4}{|c|}{ 20d. Floor material } \\
\hline Cement & Dirt & Plank Wood & Other \\
\hline
\end{tabular}

20e. Wall material

\begin{tabular}{|l|l|l|l|l|}
\hline Cement & Wood (plank) & coral & Bamboo & Other \\
\hline
\end{tabular}

\begin{tabular}{|l|l|l|l|}
\hline Paint & No paint & Local paint & painted \\
\hline
\end{tabular}


20f. Toilet

Flush toilet Outhouse Public toilet No toilet Other

\section{COMMUNITY INVOLVEMENT}

21. Do you know any fisheries staff? Yes/No

If yes, how? a) Relative

b) Friend

c) Associate

d) other

22a. Do you belong to any community organizations? many?

c. Are you involved in any fishing or conservation groups?

23a. If there is a decision to be made in your community, are you involved in that decision?

b. How (active or passive)?

24a Are you involved in decisions about marine resource use or management? b. How (active or passive)?

15. Now I want to ask you some questions about how much you trust different types of people. In general, how much do you trust?

\begin{tabular}{|l|l|l|l|l|l|l|}
\hline & $\begin{array}{l}\text { Not at } \\
\text { all } \\
\text { more } \\
\text { people } \\
\text { than trust }\end{array}$ & $\begin{array}{l}\text { Distrust } \\
\text { half }\end{array}$ & $\begin{array}{l}\text { Trust } \\
\text { more } \\
\text { people } \\
\text { than } \\
\text { distrust }\end{array}$ & $\begin{array}{l}\text { Trust } \\
\text { all }\end{array}$ & $\begin{array}{l}\text { DK/ } \\
\text { NA }\end{array}$ \\
\hline $\begin{array}{l}\text { a. People in your village } \\
\text { (e.g. Community leaders } \\
\text { neighborhood secretary) }\end{array}$ & & & & & & \\
\hline c. CCP leaders & & & & & & \\
\hline
\end{tabular}


Appendix 2. Description of variables collected in the field survey interviews and used in the analyses in the 4 WIO countries

\begin{tabular}{|c|c|c|}
\hline Data & Description & Data type \\
\hline \multicolumn{3}{|l|}{ Dependents variables } \\
\hline Level of agreement & $\begin{array}{l}\text { Perceptions on various } \\
\text { management restrictions and } \\
\text { their ability to improve fishery }\end{array}$ & Ordinal \\
\hline Perceived mean benefit disparity & $\begin{array}{l}\text { Scaling of benefit from various } \\
\text { management restrictions for } \\
\text { different social groups (self, } \\
\text { community and government) }\end{array}$ & Continuous \\
\hline \multicolumn{3}{|l|}{ Independent variables } \\
\hline Number of jobs & $\begin{array}{l}\text { Number of occupations in the } \\
\text { household }\end{array}$ & Continuous \\
\hline Years in occupation & Years one has been working & Continuous \\
\hline Residency & Years living in a place & Continuous \\
\hline Education & Years in formal education & Continuous \\
\hline Age & $\begin{array}{l}\text { Number of years of the } \\
\text { respondent }\end{array}$ & Continuous \\
\hline Expenditure & $\begin{array}{l}\text { Household biweekly expenditure } \\
\text { (US\$ in 2010) }\end{array}$ & Continuous \\
\hline Material style of life & $\begin{array}{l}\text { Principle component output } \\
\text { from summary analysis of } \\
\text { household items and type of } \\
\text { house }\end{array}$ & Continuous and unit less \\
\hline Household size & $\begin{array}{l}\text { Number of people living in a } \\
\text { house }\end{array}$ & Continuous \\
\hline \multicolumn{3}{|l|}{ Social capital } \\
\hline Community organization & $\begin{array}{l}\text { Involvement in community } \\
\text { organization and welfare groups }\end{array}$ & Binary \\
\hline Membership in fishing or & Involvement in marine related & Binary \\
\hline
\end{tabular}



Appendix 3. Study sites used in this analysis presenting the pooled scaled benefits (Mean + SEM) of the six restrictions, the within-community variation, and nearest neighbor between-community distance of pooled restrictions. Sites are arranged by country and in descending order sorted by their mean perceived benefits of restrictions.

\begin{tabular}{|c|c|c|c|c|c|}
\hline Country & Landing Sites & $\begin{array}{l}\text { Sample } \\
\text { size }\end{array}$ & $\begin{array}{l}\text { Pooled } \\
\text { Mean scaling of } \\
\text { benefits, SEM }\end{array}$ & $\begin{array}{l}\text { Within-community } \\
\text { variation, COV, \% }\end{array}$ & $\begin{array}{l}\text { Between-community } \\
\text { distance to nearest } \\
\text { neighbor. Absolute } \\
\text { values }\end{array}$ \\
\hline Kenya & Kibuyuni & 22 & $1.6 \pm 0.1$ & $17.7 \pm 5.6$ & 0.16 \\
\hline Kenya & Vipingo & 31 & $1.4 \pm 0.1$ & $23.1 \pm 5.3$ & 0.69 \\
\hline Kenya & Wasini & 2 & $1.4 \pm 0.1$ & 7.9. \pm 7.9 & 0.15 \\
\hline Kenya & Nyari & 26 & $1.3 \pm 0.1$ & $26.1 \pm 6.3$ & 0.89 \\
\hline Kenya & Shimoni & 18 & $1.3 \pm 0.2$ & $31.5 \pm 6.5$ & 0.07 \\
\hline Kenya & Mkwiro & 14 & $1.2 \pm 0.2$ & $33.9 \pm 7.2$ & 0.07 \\
\hline Kenya & Mayungu & 18 & $1.1 \pm 0.2$ & $33.1 \pm 10.3$ & 0.00 \\
\hline Kenya & Mijikenda & 25 & $1.1 \pm 0.1$ & $33.2 \pm 5.7$ & 0.00 \\
\hline Kenya & Mkokoni & 13 & $0.9 \pm 0.2$ & $37.9 \pm 10.3$ & 0.82 \\
\hline Kenya & Kanamai & 11 & $0.9 \pm 0.2$ & $39.6 \pm 10.4$ & 0.02 \\
\hline Kenya & Marina & 12 & $0.8 \pm 0.2$ & $43.9 \pm 5.7$ & 0.02 \\
\hline Kenya & Bureni & 22 & $0.8 \pm 0.1$ & $43.0 \pm 7.2$ & 0.69 \\
\hline Kenya & Chale & 18 & $0.7 \pm 0.2$ & $43.3 \pm 14$ & 0.44 \\
\hline Kenya & Msanakani & 18 & $0.6 \pm 0.3$ & $48.2 \pm 8.1$ & 0.10 \\
\hline Kenya & Pate & 27 & $0.5 \pm 0.2$ & $50.0 \pm 11.9$ & 0.67 \\
\hline Kenya & Nyali & 13 & $0.5 \pm 0.1$ & $43.5 \pm 9.3$ & 0.10 \\
\hline Kenya & Bamburi & 24 & $0.5 \pm 0.1$ & $46.6 \pm 10.9$ & 0.77 \\
\hline Kenya & Mwaepe & 20 & $0.5 \pm 0.2$ & $52.2 \pm 11.6$ & 0.32 \\
\hline Kenya & Kiunga & 26 & $0.4 \pm 0.1$ & $46.5 \pm 8.9$ & 0.54 \\
\hline Kenya & Tradewinds & 12 & $0.4 \pm 0.2$ & $49.9 \pm 10.3$ & 0.07 \\
\hline Kenya & Gazi & 15 & $0.2 \pm 0.3$ & $56.2 \pm 8.9$ & 0.44 \\
\hline Kenya & Mwanyaza & 13 & $0.2 \pm 0.2$ & $58.4 \pm 12.5$ & 0.04 \\
\hline Kenya & Mvuleni & 15 & $0.1 \pm 0.2$ & $54.3 \pm 15.6$ & 0.32 \\
\hline Kenya & Kizingitini & 12 & $0.1 \pm 0.3$ & $55.8 \pm 5.3$ & 0.17 \\
\hline Kenya & Shanga Ishakani & 27 & $-0.1 \pm 0.1$ & $63.4 \pm 13.8$ & 0.17 \\
\hline Kenya & Reef & 11 & $-0.3 \pm 0.3$ & $65.0 \pm 11.7$ & 0.92 \\
\hline Kenya & Shanga Rubu & 22 & $-0.3 \pm 0.2$ & $67.0 \pm 10.9$ & 0.89 \\
\hline Tanzania & Unguja Ukuu & 30 & $1.5 \pm 0.1$ & $29.4 \pm 4.9$ & 0.31 \\
\hline Tanzania & Ushongo & 17 & $1.3 \pm 0.1$ & $28.4 \pm 8.1$ & 0.65 \\
\hline Tanzania & Nyamanzi & 23 & $1.2 \pm 0.2$ & $34.8 \pm 3.0$ & 0.31 \\
\hline Tanzania & Wesha & 30 & $1.2 \pm 0.1$ & $33.7 \pm 4.7$ & 0.23 \\
\hline Tanzania & Mwarongo & 31 & $1.0 \pm 0.2$ & $37.7 \pm 4.0$ & 0.39 \\
\hline Tanzania & Ndagoni & 30 & $1.0 \pm 0.2$ & $39.0 \pm 6.0$ & 0.23 \\
\hline Tanzania & Wete & 30 & $0.9 \pm 0.2$ & $42.1 \pm 3.4$ & 1.24 \\
\hline Tanzania & Msasani & 20 & $0.8 \pm 0.2$ & $42.4 \pm 6.5$ & 0.09 \\
\hline
\end{tabular}




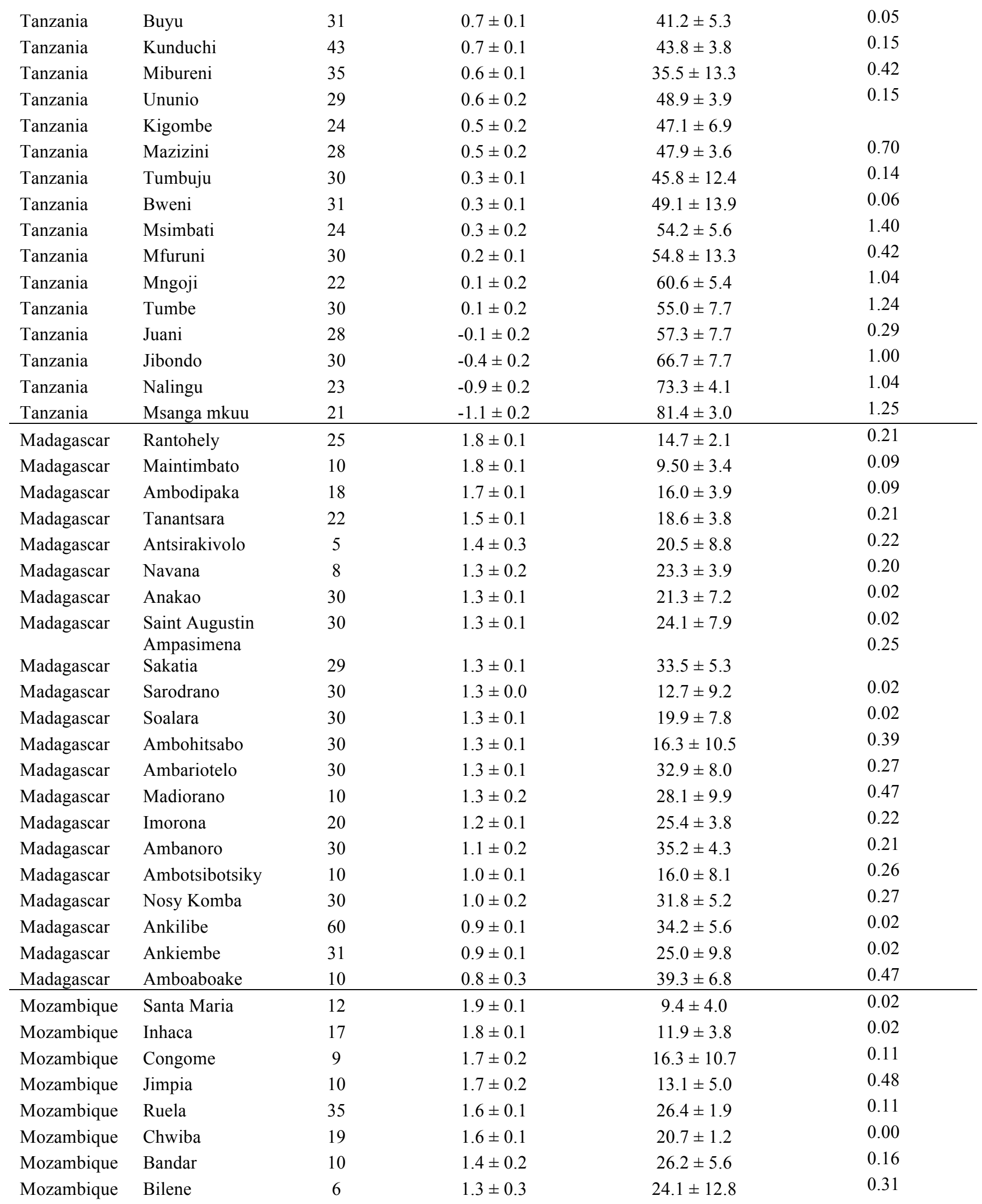




\begin{tabular}{llcccc} 
Mozambique & Marinha & 9 & $1.2 \pm 0.3$ & $26.8 \pm 9.3$ & 0.40 \\
Mozambique & Vamizi & 44 & $1.0 \pm 0.2$ & $28.9 \pm 3.6$ & 0.26 \\
Mozambique & Xai-Xai & 9 & $0.9 \pm 0.1$ & $31.8 \pm 16.9$ & 0.31 \\
Mozambique & Museu & 4 & $0.9 \pm 0.4$ & $38.0 \pm 15.4$ & 0.26 \\
Mozambique & Passo-Mar & 25 & $0.8 \pm 0.1$ & $36.6 \pm 8.0$ & 0.31 \\
Mozambique & Nacaramo & 15 & $0.5 \pm 0.2$ & $42.9 \pm 8.8$ & 0.31 \\
\hline
\end{tabular}


Appendix 4. High resolution maps and insets showing the distributions of the within and between community variation for the 6 management restrictions. Colors indicate the level of variation between communities based on z-scores of the inter-community variation. The size of the circles indicates the within community level of agreement with restriction.

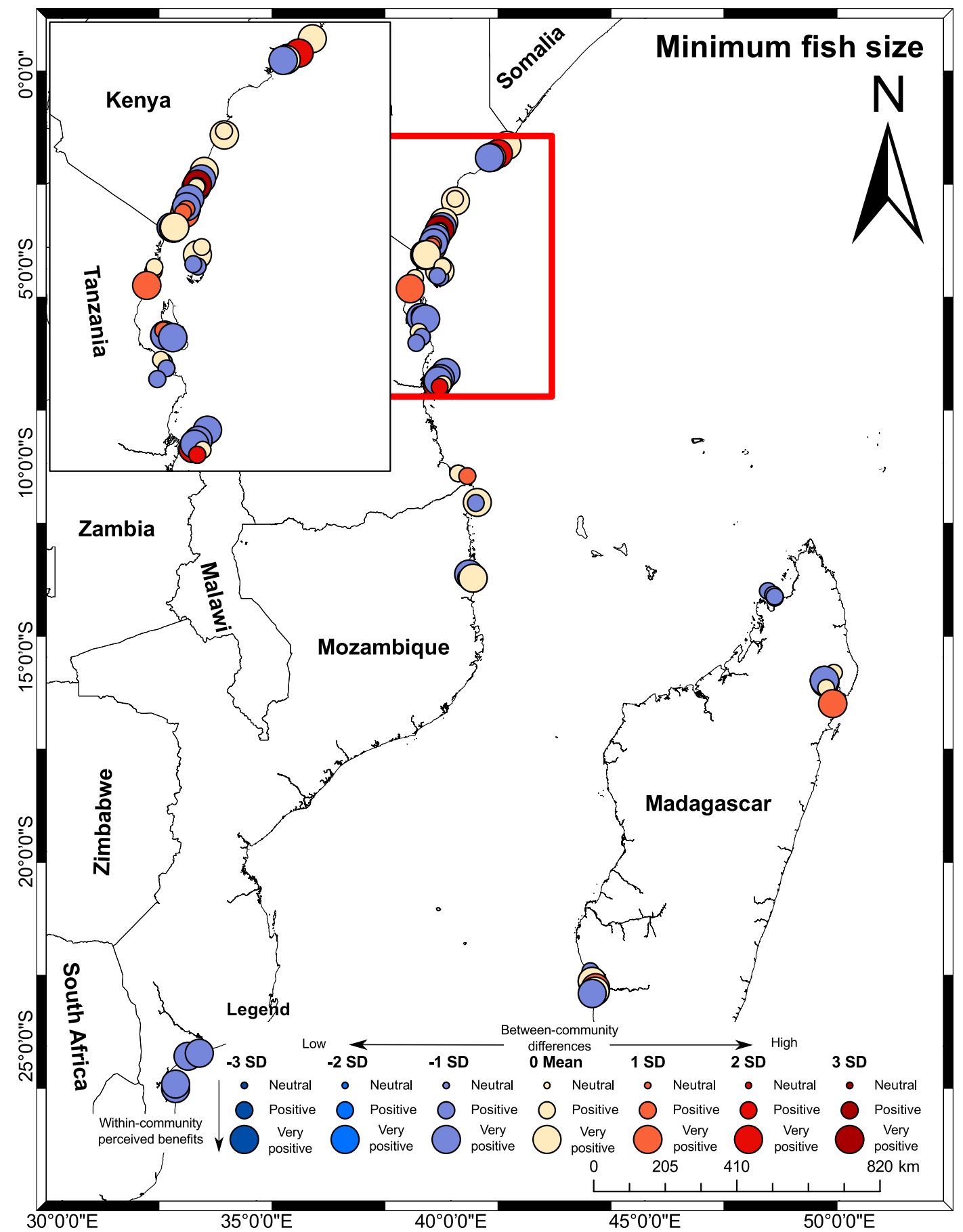




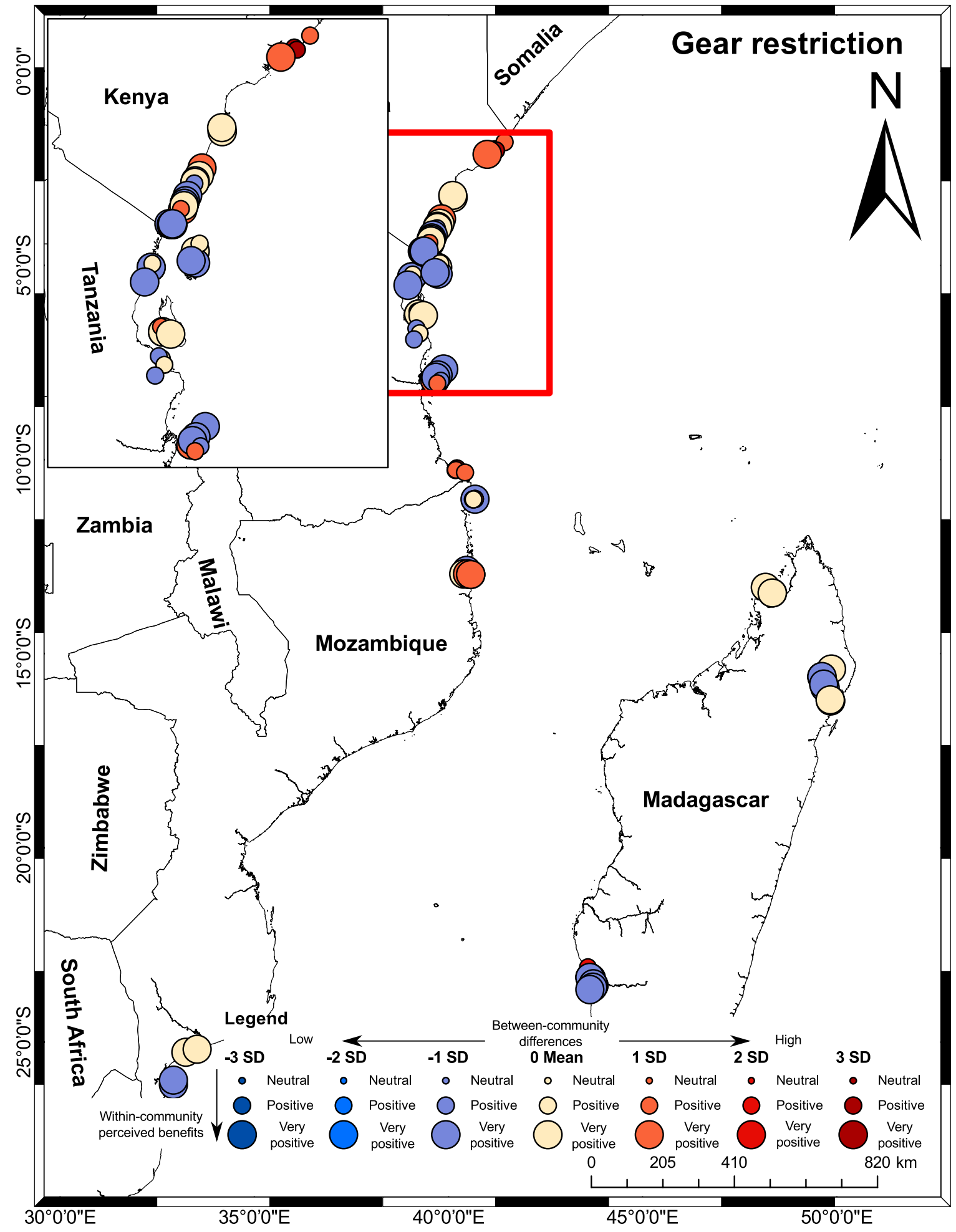




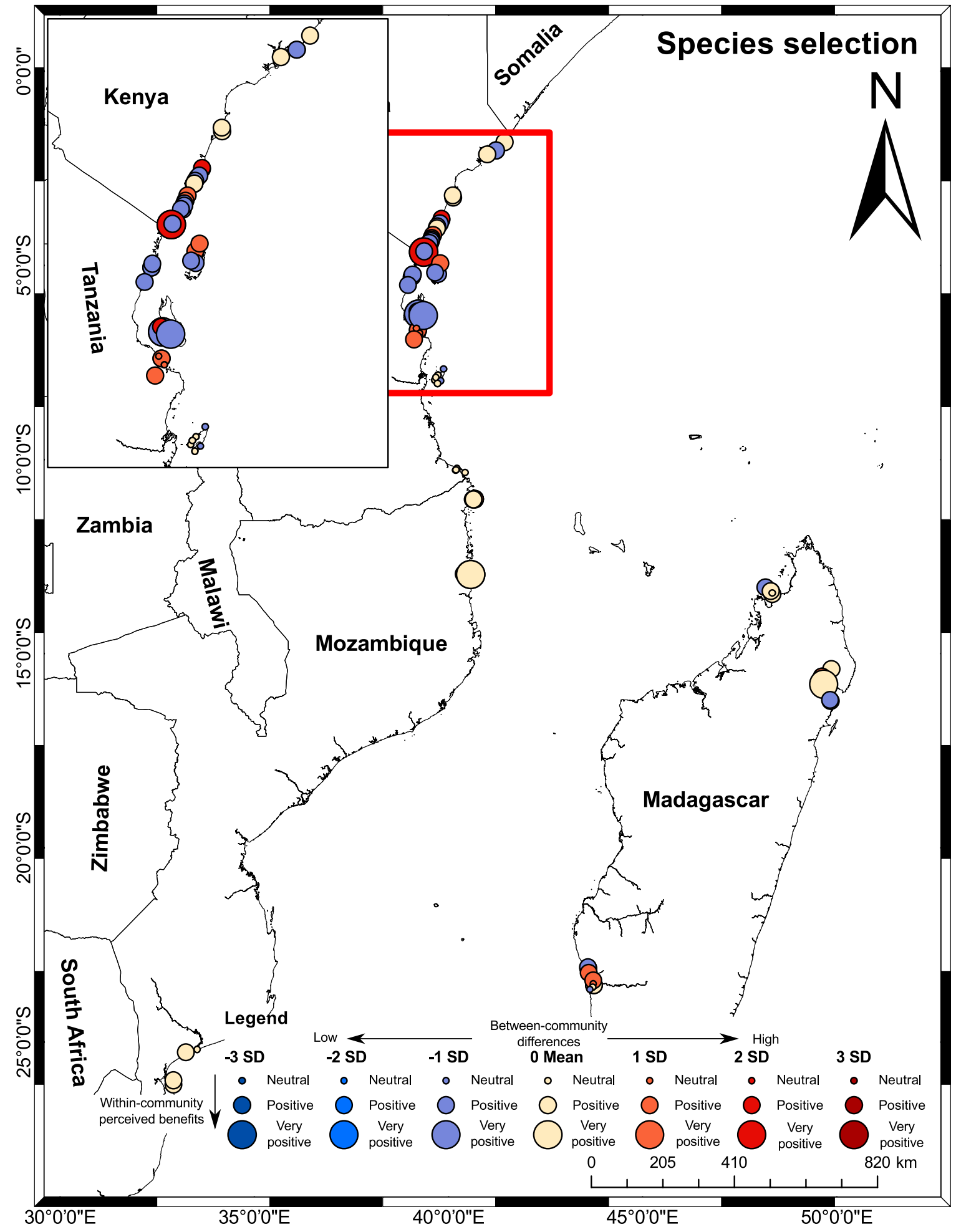




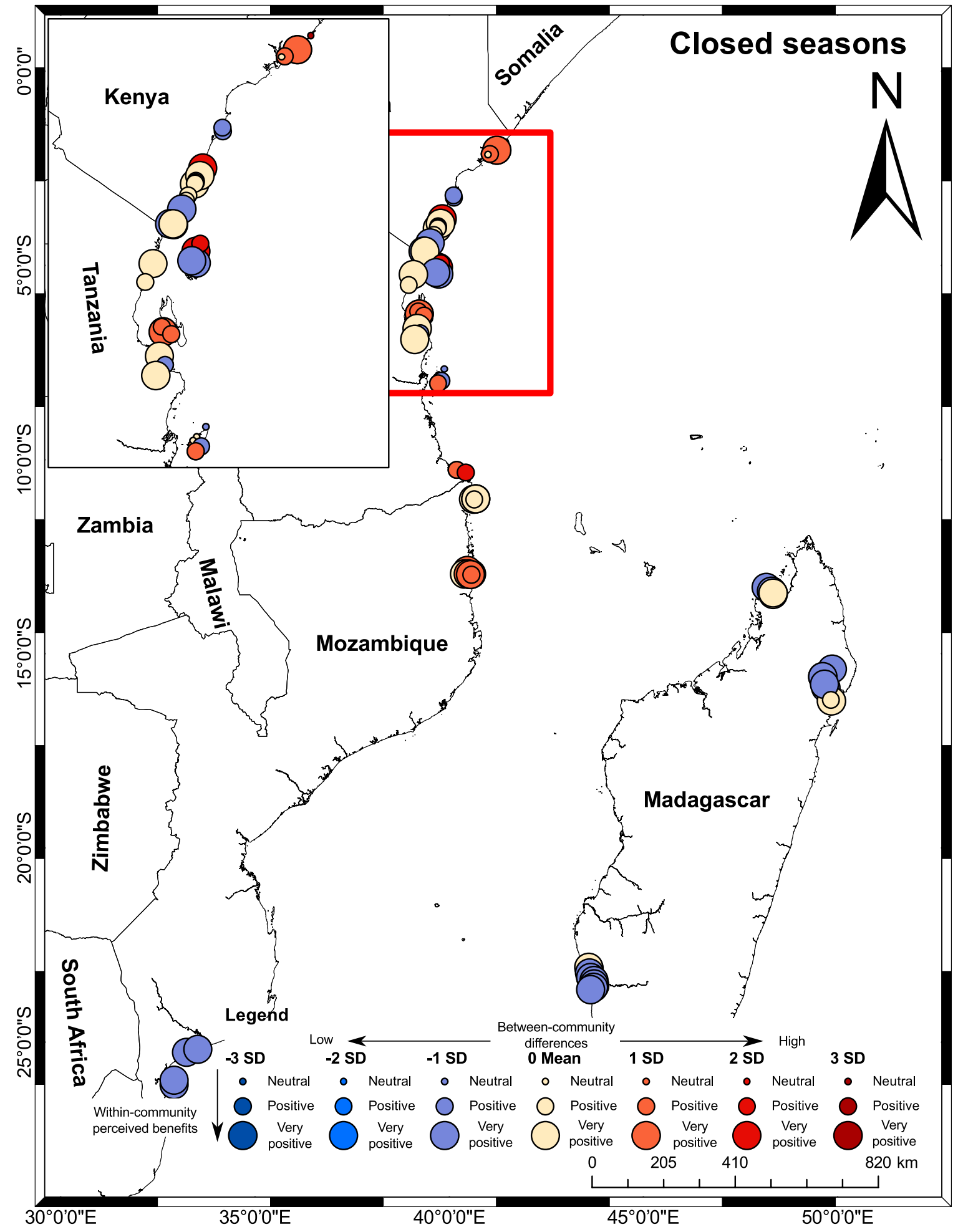




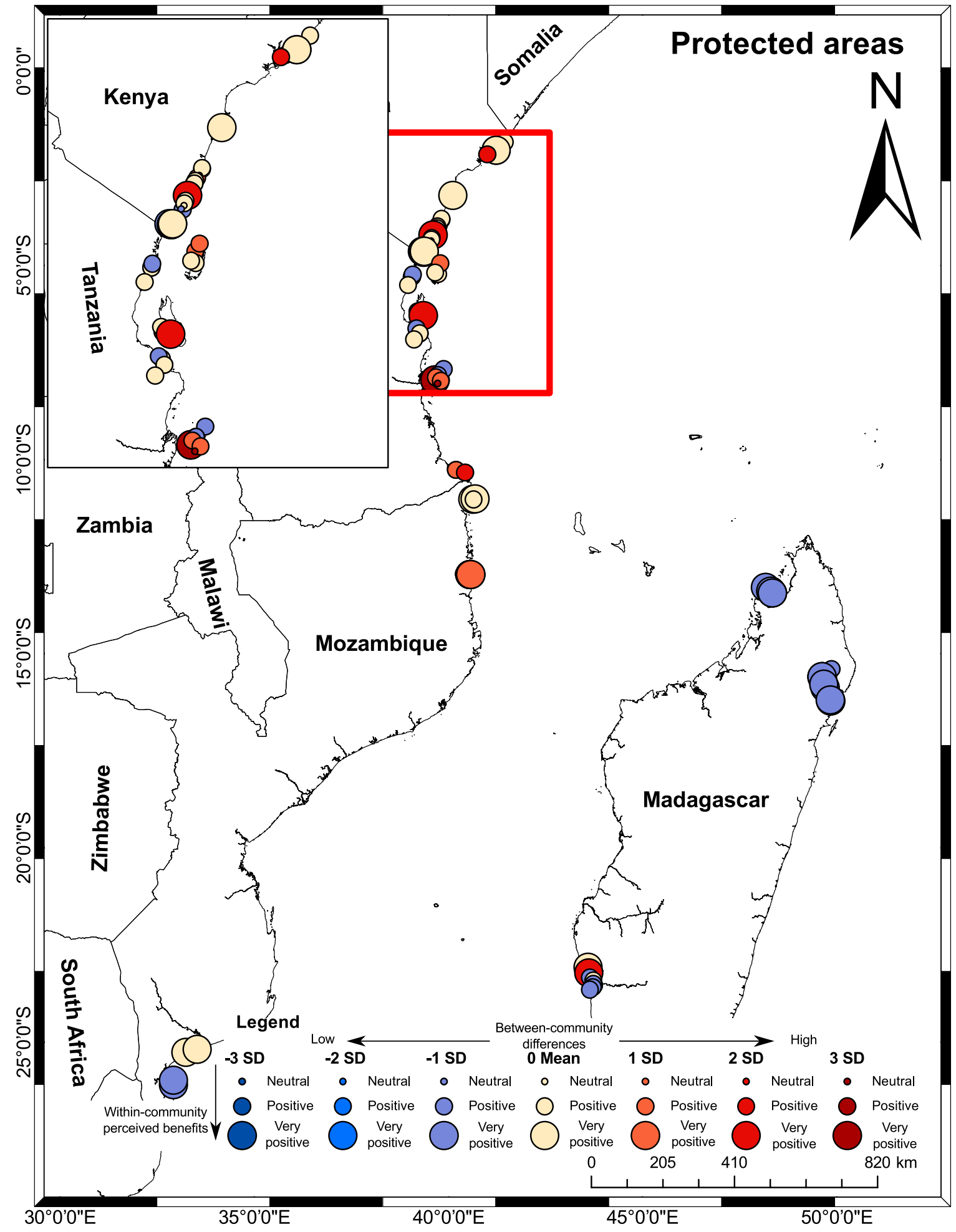




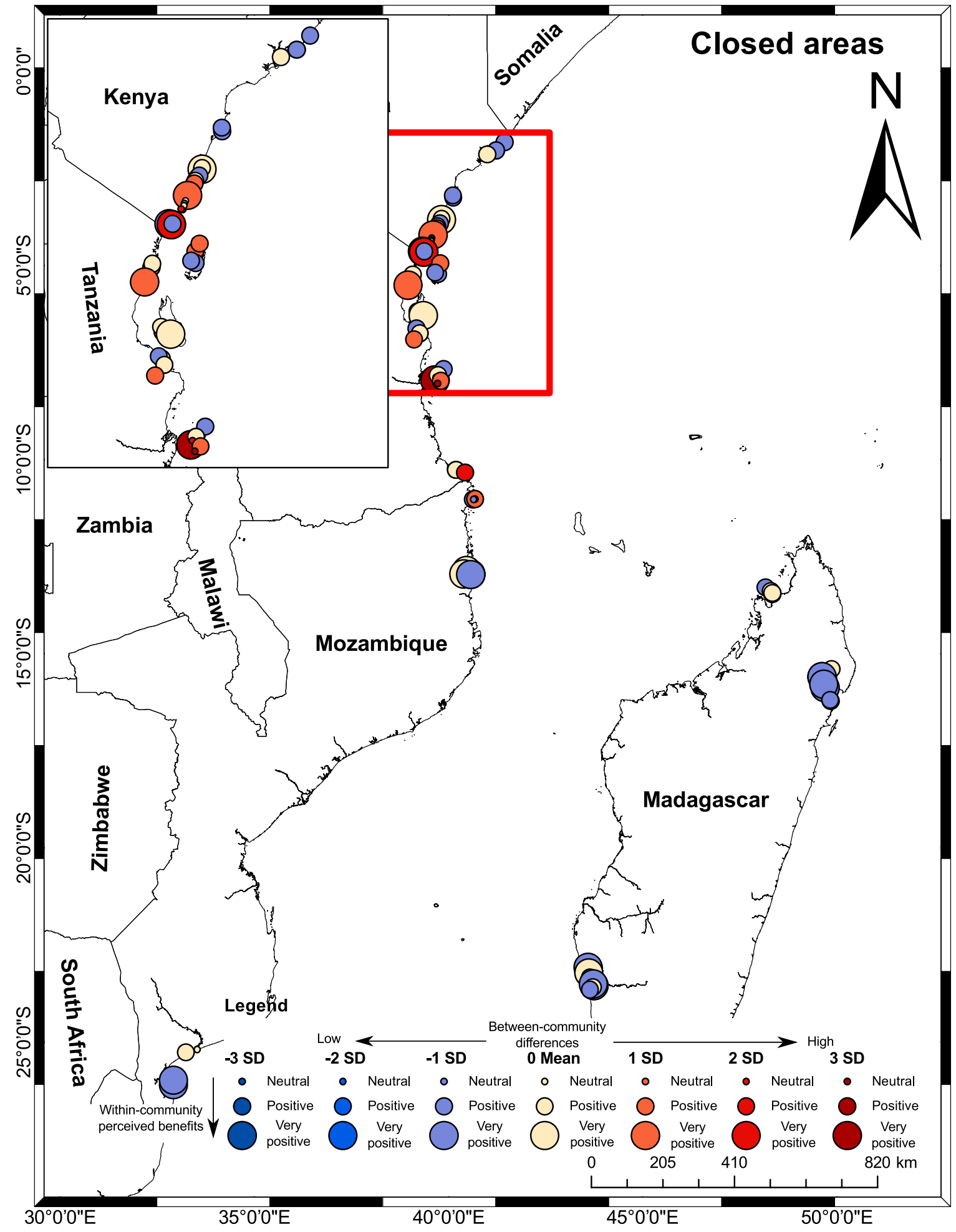

